\title{
Prevalence, Pattern and Consequences of Insecurity in Nigerian Cities ${ }^{1}$
}

\author{
Etannibi E. O. Alemika
}

\begin{abstract}
Nigeria's democratic transition and economic development are being threatened by insecurity. Since the return to civil rule in 1999, the nation has suffered several violent conflicts in which thousands of lives were lost. In this study, we analysed the prevalence and effects of insecurity in eleven Nigerian cities. Based on the data collected from 2,750 respondents in 11 cities, we find that violent conflicts are generally precipitated by ethnic, religious and electoral grievances. However, we also find that the salience of these factors in violent conflict vary across cities. The major effects of insecurity in Nigerian cities were homelessness (internal displacement), loss of employment, destruction of educational institutions, increased criminal activities, and high food prices. Nigerians were generally dissatisfied with the police, which they perceive as ineffective in preventing or curtailing violent conflicts. The findings underscore the need for policies aimed at strengthening national integration through programmes and actions that protect the rights of citizens to religion, residence, political inclusion and equal access to social services provided by government without discrimination on grounds of ethnicity, religion, place of birth and origin, gender and political association
\end{abstract}

\section{Introduction}

Studies by criminologists and sociologists have shown that insecurity - conflict and crime - are more prevalent in the cities than in the rural communities. The prevalence of insecurity in cities has been attributed to their characteristics as "a motley of peoples and cultures, of highly differentiated modes of life between which there often is only the faintest communication, the greatest indifference and the broadest tolerance, occasionally bitter strife, but always the sharpest contrast" (Wirth 1938: 20). According

\footnotetext{
${ }^{1}$ This paper is an output of a research under the auspices of Improving Institutions for Pro-Poor Growth (iiG), an international network of applied research institutes and researchers across Africa, Asia, the USA and Europe, lead by the Centre for the Study of African Economies at the University of Oxford; working to generate new insights about institutions' influence on pro-poor growth through an innovative programme of research, capacity building, and dissemination. $\mathrm{iiG}$ research is funded by the UK Department for International Development (DFID), The William and Flora Hewlett Foundation and the Open Society Institute. The views expressed in this document are not necessarily those of the funders.
} 
to Wirth (1938: 23), personal "disorganization, mental breakdown, ${ }^{*}$ suicide, delinquency, crime, corruption, and disorder" are "more prevalent in the urban than in the rural community".

The interdependence of life in the city, which represents, in the Durkhemian sense, the dominance of organic form of solidarity rather than mechanical solidarity, enriched social life. However, it is also a source of several forms of social pathology due to institutional dysfunctions and disjuncture between expectation and achievement (Merton 1938). This logic of differentiation and fragmentation of lived experiences in different cities and urban spaces informs this study of insecurity and conflicts across cities in Nigeria. Conflicts in Nigeria have largely been associated with ethnicity, religion, politics and indigene versus non-indigene antagonisms. These are generally instrumental factors used in the straggles for the control of state power and appropriation of public resources.

The absence of an institutionalised or consolidated democratic culture coupled with weak regulatory, policing and judicial systems engender lack of capacity for the prevention and resolution of conflicting interests in Nigeria. In democratic societies, the police are primarily responsible for using legal powers granted to them to prevent and mitigate conflicts. However, experience since 1999 has shown high incidence and prevalence of violent conflicts and violent crimes, which the police failed to bring under control within reasonable time. Our objectives in this article are two-fold: (a) to determine the sources, types and effects of conflicts in Nigeria, and (b) to examine public perspectives on the effectiveness of the police in conflict prevention and mitigation, trust in the police, satisfaction with police service.

\section{Literature}

Sociologists traditionally define the city in terms of empirical characteristics like large, dense and heterogeneous population; high rate of migration; anonymity, diversity and conflict of values and norms; socioeconomic inequality that tends to coincide with residential patterns; social disorder and disorganisation, decline of kinship relations and significance of impersonal rules. Louis Wirth defines the city as "a relatively large, dense, and permanent settlement of heterogeneous individuals" (1938: 1).

Wirth (1981) suggested that the large numbers of persons in cities "account for individual variability, the relative absence of intimate personal acquaintanceship, the segmentalization of human relations which are largely anonymous, superficial, and transitory, and associated characteristics". One of the characteristics of the city identified by Wirth that is relevant to our study is that heterogeneity "tends to break down rigid social structures and to produce increased mobility, instability, and insecurity, and the affiliation of the individuals with a variety of intersecting and tangential social groups with a high rate of membership turnover". 
The development of the city is often regarded as a precondition for economic growth. Cities grow through the natural process of the fertility of the residents $/$ and more importantly through the attraction of rural dwellers. The rural dwellers are drawn to the city because of the concentration of:

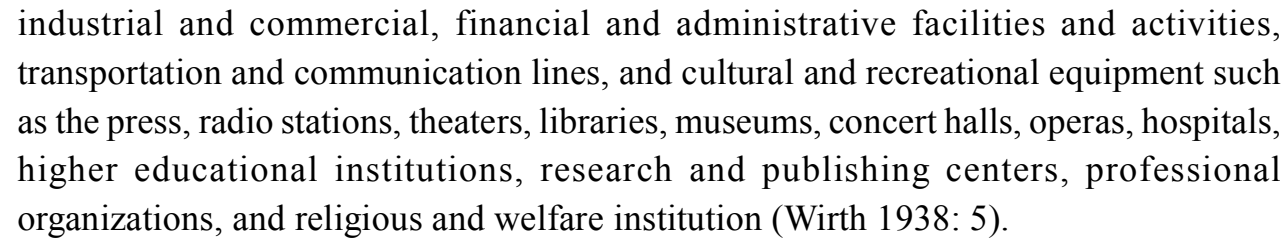

Sociological literature indicates that violent crimes are higher in cities than rural settlements. Urban violence has been explained as the effect of poor or low income; unemployment; exclusion from vital social services (shelter, education, health, transportation and sanitation), wide income inequalities; overcrowded and dilapidated housing structures; insecure housing tenure; consumerist culture, and disadvantages that sometimes correlate with social (ethnic, religious and national) identities (Ley 1974; Moser 2004; Muller and Seligson 1987; Vanderschueren 1996; Winton 2004; UNCHS, 1996, Stewart 2000).

\section{Cities, Social Order, Social Conflict and Insecurity}

The city is a space with many contradictions and contrasts: opportunities and deprivations; fragmentation, interdependence and exclusion; wealth and affluence of a minority on one hand and abject poverty of a majority on the other; power and powerlessness; physical proximity and social relation at a distance, and,violence and security (Moser 2004; Fischer 1975; Kraxberger 2005; Caldeira 1996). The social ecological approach in urban sociology pioneered by the University of Chicago sociologists in the 1920s suggests that crime and other social problems vary across the concentric zones or neighbourhoods within the city. Zones and neighbourhoods characterised by high immigrants, and high population density, heterogeneity and turnover have higher incidences of crime, delinquency, and other social and economic problems. As Howard (2003: 201) notes:

African cities contain sites of danger and opportunity, of fear and hope ... while people have confronted one another along lines of class, gender, age, ethnicity, and religion, through their interaction, they also have redefined the content of such categories.

Simone argued that African cities "are largely sites of intensifying and broadening impoverishment and rampant informality operating on highly insubstantial economic platforms through which it is difficult to discern any sense of long-term viability" (Simone 2001: 15). He further noted that it is the cities that "Africans have most intensely engaged the conflicts precipitated by their own points of view, their political and economic practices, and their heterogeneous, often contradictory, representations of outside worlds" (Simone 2001: 20).

18 Annals of the Social Science Academy of Nigeria, No 20, 2015 
Tilly provides us with useful insights into the forms, scale and flow of violent conflicts, especially of ethnic, religious, political and economic types that are commonly witnessed in Nigeria. Political, ethnic and religious entrepreneurs mobilize one group against another or others, often to benefit themselves more than the generality of the group memberships, which they claim to, represent in the articulation of grievances and negotiating settlement.

Several conflict-inducing factors have been identified in the literature (Alemika 2002; Winston 2004, Moser 2004). The literature has identified several sources of insecurity like violent conflicts and crime, in specific contexts. A recent review of the literature identified the following factors as causes or triggers of insecurity, poverty and development: inequality between richer and poorer households; unemployment, corruption and exclusion; low incomes, high unemployment, and inequality of different sorts; rapid urbanisation; severe competition among ethnic, religious and regional groups; real or perceived discrimination and human rights violations or abuses; experience and feeling of or imagined relative deprivaiior*; frustration of expectations for anticipated or merited socioeconomic benefits or opportunities, and oppression or marginalisation (World Bank 2011).

\section{Effects of Insecurity}

The relationship between, security, growth, poverty reduction and development has received significant attention from researchers, international development assistance agencies and national governments. The security-development nexus has largely been investigated within the context of civil war or intra/inter-state conflicts (Stewart 2004). However, the insecurity encountered in Nigerian cities has arisen more from criminality, especially armed robbery and ethno-religious conflicts, often rooted in competition for the control of state power and economic resources. OECD (2007:5) stated that insecurity constitutes barriers "to political, economic and social development". Further, as an OECD-DAC Report has argued, "security and development are linked. Insecurity, crime and violent conflicts are among the biggest obstacles to the achievement of the Millennium Development Goals; they also destroy development" (OECD 2007: 5). The Report observed that security is important 'to the well-being of the poor' and 'supporting poor people's physical security is vital part of reducing poverty’ (OECD 2007:5).

Conflicts have diverse effect on the economy, including poverty reduction. Among such effects are decreased participation in productive economic activities; destruction of human and material resources; reduction in investment and diversion of resources for social services and infrastructural development to conflict-mitigation (Stewart 2003, 2004). The World Bank (2011: 59) notes that the "costs of violence for citizens, communities, countries, and the world are enormous, both in terms of human suffering and social and economic consequences. The costs are both direct (loss of life, disability, and destruction) and indirect (prevention, instability, and displacement)" (p. 59). 
Cities differ in terms of their dominant characteristic factors, especially determined by their evolution and economic substructure (Weber 1961). Cities dominated by financial, commercial, industrial and state bureaucratic activities tend to differ from each other in the nature of the social interaction, social life, social solidarity and conflicts (Wirth 1938). Cities differ in terms of population, economic and social composition; quality of social life and extent of insecurity and conflicts across neighbourhoods. According to Howard (2003: 198), "particular places, neighborhoods, and even huge urban agglomerations have been given their character through discourse about them and through public dramas" that often involve "rhetoric of rights and controls, belonging and exclusion". Cities exhibit absence of dominant cultural values and social control that engender anomie and feelings of instability and insecurity (Weber 1961; Wirth 1938).

\section{Nature and Sources of Insecurity: Violent Conflict and Crime}

Conflict may be constructive, transformative or destructive. The effects of conflicts depend on their scope, duration and more importantly how they are expressed and managed. Conflicts tend to become violent when a society lacks effective institutionalized mechanisms for regulation. Social conflict, according to Obserchall (1978:291), "encompasses a broad range of social phenomena: class, racial, religious, and communal conflicts; riots, rebellion, revolutions; strikes and civil disorders, marches, demonstrations, protest gatherings and the like". Coser (1967: 232) stresses the instrumental character of social conflict, by defining it as "a struggle over values or claims to status, power, and scarce resources, in which the aims of the conflict groups are not only to gain the desired values, but also to neutralize, injure or eliminate rivals". Not all conflicts involve violence, which Schmid (1998: 23) defined as:

... direct physical hurt or harm to someone's bodily integrity (violation as in torture, rape, mutilation, and beating) and ultimately life itself (killing). It can be a result of an aggressive attitude (or impulse) or of instrumental behaviour meant to injure or destroy human beings in order to achieve a variety of ends, such as enforcing (or avoiding) dominance.

Predisposition to violent conduct varies among nations, cultures, ethnic and religious groups because of variation or differences in socialization and normative prescriptions concerning violence (Wolfgang and Ferracutti 1967). Tilly (2003) identified two groups of actors that are critical to the initiation, pattern, scale and termination of collective violence (violent conflicts). These are the political entrepreneurs and specialists in the deployment of violent means. He argued that political entrepreneurs "specialize in activation, connection, coordination and representation" (p.34). The political entrepreneurs activate, (and sometimes deactivate) boundaries, stories, and relations, connect (and sometimes disconnect) distinct groups and networks (p.34). Tilly noted that the "political entrepreneurs wield significant influence dver the presence, absence, form, loci, and intensity of collective violence" (p.34). 
Violence destroys life; impairs human welfare and social solidarity; destroys infrastructure; erodes capacity and opportunities for productive economic enterprises; constrains social interaction; depletes personal and community economic assets, and diverts personal community and state resources from developmental and welfare programmes to efforts aimed at preventing, resolving and mitigating conflicts and violence.

\section{Violent Crimes in Nigeria}

Violent crimes have been a major source of concern to the public and government during the past two decades spanning military and civilian regimes. Armed robbery in particular has dominated the public psyche in the perception of insecurity in the country. Many economic activities have been adversely affected by the incidence and fear of armed robbery. Petrol stations that once operated for twenty-four hours a day now close business before sunset in order to avoid being victims of robbery. Similarly, informal night trading has been adversely affected in many cities where violent conflicts' and crimes are prevalent. A national crime victimization survey conducted by CLEEN Foundation in 2011 discovered that about one in eight respondents (13.5\%) reported that they were victims of armed robbery in 2010 . When asked about the crimes they feared most, armed robbery and murder were identified crimes by $71.4 \%$ and $70.2 \%$ respectively. Armed robbery was identified as the most prevalent neighbourhood crime and disorder problem reported by the respondents (16.1\%) in the CLEEN Foundation national criminal survey in 2009 . When asked what should be the priority of the police, containment of armed robbery was the most mentioned. More than one in five respondents $(22.3 \%)$ in the 2009 survey asked the police to make this a priority. The Nigeria Police crime statistics reported the following incidence of armed robbery, murder and kidnapping in the country from 2005 to $2008 .^{2}$

Data collated from the Annual Report of the Nigeria Police Force for the years 2005 to 2009 indicated the following information about armed robbery incidence and casualty in Nigeria: 16, 925 cases of armed robbery were recorded during the five year period; 1,043 civilians were killed during robbery operations by robbers; 2,216 armed robbery suspects were killed during encounter with the police, and 517 police officers lost their lives during their encounter with suspected armed robbers. Also, kidnapping for ransom has also become a major problem in the country, especially in the South-Eastem and South-South zones of the country. Available statistics from the police showed that from "January 2008 - June 2010, more than a thousand and two hundred cases of kidnapping were recorded" (Alemika 2010: 9). It was observed that:

${ }^{2}$ Nigeria Police Crime statistics grossly under-record crime due to several reasons, including inadequate appreciation of the importance of crime record keeping and analysis to aid policy, planning and management (Alemika 2004d). 
Persons kidnapped included foreigners, Nigerian politicians, relatives of politicians and business tycoons, priests, artistes, professionals like doctors, lecturers, lawyers, journalists and children. In many cases, the ransom demanded were, according to media reports, negotiated, paid and victims released. Kidnappings occurred in different places like highways, roads within city and villages; places of worship, schools, offices, homes, etc. The crime has become pervasive ... (Alemika 2010: 9).

\section{Violent Ethnic and Religious Conflicts in Nigeria}

Ethnicity and religion are increasingly politicised and used as strategic resource to access resources within the state or to create space for participation and inclusion in the public sphere (Nnoli 1978; Alemika 2007, 2005, 2004a, 2004b, 2004c; 2002; CLEEN \& OMCT, 2002; Ibrahim, 2000; Jega 2000; Kukah 1993; Mu'azzam Ibrahim 2000; Mustapha 2000; Olaniyi 2006; Otite 1990; Suberu 2001). The politicization of ethnicity and religion has occurred in the context of bad governance and weak state capacity (Ibrahim, 2000; Jega 2000; Mu'azzam Ibrahim 2000; Mustapha 2000). The worsening problem of poverty, deterioration of social infrastructure and services, loss of employment due to decline in the real sector of the economy and retrenchment in public service, food insecurity, high rural-urban migration, growing mass unemployment especially among young persons provided fertile ground for disaffection, inter-group competition and violence in the country. In the absence of social safety net, deprived individuals tend to seek and find refuge and relevance in primordial networks (Jega 2000; Ibrahim 2000; Mu'azzam and Ibrahim 2000; Mustapha 2000).

Since the time of transition to civil rule in May 1999, Nigeria has recorded numerous incidences of ethno-religious and communal violence. Violent conflicts involving loss of lives and large scale destruction of property have occurred in the cities of Shagamu, Lagos, Kaduna, Kano, Ibadan, Aba, Owo and Warri as well as in various parts of Plateau, Rivers, Benue, Taraba, Bayelsa, Adamawa, Nasarawa, Akwa Ibom and Kwara States. Ethnoreligious conflicts have claimed several thousand lives since 1999. For example, the White Paper, issued by the Kaduna State Government, on the February 2000 religious crisis precipitated by the state government's attempt to introduce Sharia criminal law reported that "a total of 1,295 persons died, unspecified number were buried unidentified, while some were declared missing".

A group of extremist Muslims (self-styled as Boko Haram) came to the public scene in 2009. Since then, the activities of members of the sect have become major security threats. Members of the sect have carried out numerous violent criminal activities such as bombing of critical public buildings (e.g. UN office and Police Force Headquarters in Abuja), security establishments, churches, educational institutions and recreational centres in several cities in the Northern States of Bauchi, Yobe, Kano, Plateau, Adamawa, Taraba and especially Borno. An internal police operations report revealed that seven hundred people were reported killed during the violent conflict initiated by the sect in July 2009. In the early 1980s, the country witnessed a similar uprising by a Muslim extreme group led by Maitatsine. The religious riots which started in Kano in 
1980 spread to Bauchi, Yola and several cities in the northern part of the country, and thousands of people died because of the insurgency. Between 1994 and 2006, \%n ethnic militia known as Odu'a People's Congress also emerged as insurgent group in the SouthWest region of the country. Nigeria also witnessed the emergence of several insurgent groups in the Niger Delta from the early 2000s until 2008. These groups still exist in the country, although their activities have become less militant.

\section{Research Settings}

Nigeria is a federal state with 36 states and a Federal Capital Territory further carved into 774 local government areas. It has a population of 140 million according to the national census conducted in 2006. There are nearly four hundred ethno-linguistic groups in the country (Otite 1991). These ethnic-nationalities were brought together during the one-hundred year long British colonial expedition (1861-1960) through series of amalgamations culminated in the grand amalgamation of the Colony of Lagos and the Southern and Northern Protectorates (products of serial amalgamation of ethnic nationalities in the South, Central and Northern Nigeria) as a colonial Nigeria state in 1914.

There are three dominant ethnic groups in Nigeria: Hausa in the North, Igbo in the East, and the Yoruba in the West. These groups make up around two-thirds of the total population. There are more than three hundred and seventy other ethnic groups (Otite 1991), the majority of which are located in the central parts of Nigeria in Adamawa, Plateau, Kogi, Kaduna, Nasarawa, Borao, Taraba, Niger, Kebbi, Yobe, Gombe, and Kwara states. Many ethnic groups are also found in Edo, Delta, Rivers, Cross-River, Akwa Ibom, and Ondo states in the southern part of the country. Christianity (predominantly in the south) and Islam (predominantly in the north) are the two major religions in Nigeria. However, Syncretism is common in the country and adherents of the major religions spice their beliefs with traditional religious practices.

\section{Method and Data Collection}

The data for this study were collected under the Nigeria project within the Improving Institutions for Pro-Poor Growth (iiG) research programme at Oxford University, in the United Kingdom. The Nigeria Project has three main research areas: (a) policing security and investment; (b) tax and political accountability, and (c) politics, identity and investment. Data for the study were collected at the individual level through household surveys in eleven cities within eleven states across five of the six geo-political zones in the country. The cities, states and geo-political zones are as follow:

a) Enugu - Enugu State - South-East

b) Kaduna - Kaduna State - North-West

c) Kano - Kano State - North-West

d) Lagos - Lagos State - South-West -

e) Lafia - Nasarawa State - North Central 
f) Ibadan - Oyo State - South-West

g) Jos - Plateau State - North-Central

h) Bauchi - Bauchi State - North-East

i) Sokoto - Sokoto State - North-West

j) Onitsha - Anambra State - South-East

k) Aba - Abia State - South-East

All the cities, except Onitsha, were state capitals. Onitsha was chosen because it was more cosmopolitan than the state capital and had a long history of being a centre of commerce.

A pilot study was conducted in Lagos, the country's economic capital. The study aims at examining the impact of governance (taxation, accountability and service delivery) and security on the political and economic attitudes and behaviours of citizens, including likelihood of entrepreneurial activities and other investments, which are necessary for sustained economic growth and poverty reduction.

The respondents for this study were adult Nigerian males and females aged 18 years and above. To qualify for selection, they must also have stayed in the 'selected household for a period of not less than six months. Non-Nigerian citizens, people aged less than eighteen years and people living in institutionalized settings were not eligible for the survey. Two hundred and fifty respondents were selected in each city. Two hundred and fifty $(2,750)$ respondents $(1,377$ males and 1,373 females) were interviewed in the eleven cities across eleven states.

The interview schedule was designed to collect information on a range of economic, governance and security conditions and perceptions from Nigerian citizens in the eleven cities. It was translated from English to Hausa Igbo, Yoruba and Pidgin English. The fieldwork was conducted $7^{\text {th }}$ to $21^{\text {st }}$ December 2010 by Practical Sampling International, an experienced social survey firm based in Lagos, with close supervision from the research team.

\section{Results and Discussion}

Socioeconomic, ethnic and religious backgrounds of respondents

The socioeconomic, religious and ethnic backgrounds of the respondents are presented in tables 1 and 2. 
Table 1: Age, Income and Education of Respondents

\begin{tabular}{|l|c|c|c|c|c|c|c|c|c|c|c|}
\hline \multirow{2}{*}{ Cities } & \multicolumn{3}{|c|}{ Age (years) } & \multicolumn{1}{|c|}{ Income in 000 Naira } & \multicolumn{6}{c|}{ Education } \\
\cline { 2 - 14 } & $\begin{array}{l}18- \\
24\end{array}$ & $\begin{array}{c}25- \\
34\end{array}$ & $\begin{array}{c}35- \\
54\end{array}$ & $55+$ & $\begin{array}{c}15 \text { or } \\
\text { less }\end{array}$ & $\begin{array}{c}16- \\
35\end{array}$ & $\begin{array}{c}36- \\
55\end{array}$ & $56+$ & $\begin{array}{l}\text { Primary } \\
\text { or less }\end{array}$ & Secondary & Tertiary \\
\hline Enugu & 65.5 & 15.5 & 17.7 & 1.4 & 63.8 & 21.9 & 10.7 & 3.6 & 8.6 & 36.2 & 55.3 \\
\hline Kaduna & 63.8 & 18.3 & 16.0 & 1.9 & 72.1 & 19.2 & 5.9 & 2.7 & 21.2 & 38.2 & 40.6 \\
\hline Kano & 68.2 & 17.9 & 12.1 & 1.8 & 82.8 & 14.8 & 1.0 & 1.5 & 17.6 & 52.7 & 29.7 \\
\hline Lagos & 62.5 & 22.9 & 13.8 & 0.8 & 52.0 & 30.5 & 13.5 & 4.0 & 14.1 & 38.0 & 47.9 \\
\hline Lafia & 71.8 & 17.3 & 9.5 & 1.4 & 78.5 & 14.9 & 5.3 & 1.3 & 12.2 & 41.0 & 46.8 \\
\hline Ibadan & 53.2 & 22.7 & 21.8 & 2.3 & 60.4 & 33.0 & 6.6 & 0.0 & 10.8 & 59.0 & 30.1 \\
\hline Jos & 68.3 & 15.1 & 15.6 & 0.9 & 74.6 & 16.1 & 7.3 & 2.1 & 15.6 & 40.3 & 44.2 \\
\hline Bauchi & 70.0 & 17.2 & 12.8 & 0.0 & 83.3 & 11.9 & 3.1 & 1.8 & 29.9 & 42.1 & 28.0 \\
\hline Sokoto & 66.5 & 19.1 & 12.3 & 2.1 & 65.1 & 20.3 & 8.0 & 6.6 & 30.8 & 25.8 & 43.4 \\
\hline Onitsha & 63.1 & 16.5 & 17.0 & 3.4 & 58.5 & 23.0 & 12.5 & 6.0 & 13.3 & 53.3 & 33.3 \\
\hline Aba & 65.2 & 15.6 & 17.9 & 1.3 & 64.7 & 22.3 & 10.2 & 2.8 & 6.7 & 57.6 & 35.8 \\
\hline All cities & 65.3 & 18.1 & 15.1 & 1.6 & 68.8 & 20.6 & 7.6 & 2.9 & 16.5 & 44.2 & 39.3 \\
\hline
\end{tabular}

Table 2 presents the ethnic and religious composition of the respondents in the eleven cities covered in the study.

Table 2: Ethnic and Religious Affiliations of Respondents

\begin{tabular}{|c|c|c|c|c|c|c|c|c|}
\hline \multirow[t]{2}{*}{ Cities } & \multicolumn{5}{|c|}{ Ethnic Affiliation } & \multicolumn{3}{|c|}{ Religious Affiliation } \\
\hline & $\begin{array}{l}\text { Hausa \& } \\
\text { Fulani }\end{array}$ & Igbo & Yoruba & $\begin{array}{l}\text { Other } \\
\text { Southern } \\
\text { Groups }\end{array}$ & $\begin{array}{l}\text { Other } \\
\text { Northern } \\
\text { Groups }\end{array}$ & Christianity & Islam & Others \\
\hline Enugu & 1.6 & 94.8 & 0.8 & 2.8 & 0.0 & 98.9 & 0.5 & 0.5 \\
\hline Kaduna & 55.7 & 10.4 & 12.0 & 2.6 & 19.3 & 57.9 & 42.1 & 0.0 \\
\hline Kano & 82.9 & 2.8 & 4.5 & 2.8 & 6.9 & 35.8 & 64.4 & 0.0 \\
\hline Lagos & 2.9 & 15.3 & 71.5 & 8.7 & 1.7 & 86.0 & 13.6 & 0.4 \\
\hline Lafia & 48.5 & 18.8 & 3.6 & 3.0 & 26.1 & 68.2 & 31.3 & 0.5 \\
\hline Ibadan & 4.8 & 5.2 & 88.4 & 1.6 & 0.0 & 88.3 & 11.7 & 0.0 \\
\hline Jos & 41.6 & 18.2 & 14.0 & 3.6 & 21.9 & 70.5 & 29.5 & 0.0 \\
\hline Bauchi & 81.0 & 7.6 & 2.9 & 1.0 & 7.6 & 32.7 & 67.3 & 0.0 \\
\hline Sokoto & 83.5 & 7.4 & 3.7 & 0.8 & 4.5 & 31.7 & 68.3 & 0.0 \\
\hline Onitsha & 1.6 & 97.1 & 0.4 & 0.8 & 0.0 & 98.9 & 1.1 & 0.0 \\
\hline Aba & 0.8 & 98.8 & 0.0 & 0.4 & 0.0 & 98.9 & 1.1 & 0.0 \\
\hline All cities & 35.1 & 36.5 & 19.4 & 2.5 & 6.5 & 68.03 & 1.9 & 0.1 \\
\hline
\end{tabular}

\section{Sources of Insecurity in Nigerian Cities}

Two major dimensions of insecurity are the focus of this study. These are violent conflicts and criminal victimization. One of the major problems of analysing collective violence in 'Nigeria is the high correlation between ethnicity and religion. A very significant majority of people belonging to the Hausa and Fulani ethnic groups are Muslims, just as almost every person belonging to Igbo ethnic group is Christian. In 
between these extremes are the various other ethnic groups in the country. In this circumstance, ethnic and religious grievances become difficult to distinguish. This explains the tendency to invoke the term ethno-religious conflict in describing most conflicts in the country. Identities serve various purposes in Nigeria where the state capacity to protect and serve citizens is weak and failing. They serve as anchor for the urban underprivileged-: as resource for competition for power and wealth by the elite and as instrument of manipulation by failed government.

One of the explanations of inter-group conflict is relative deprivation or horizontal inequality. It has been observed that:

Relative deprivation - the perception by one or more parties that they are being unjustly treated - is a major cause of civil war. Many conflict societies are characterised by large inequalities in access to the productive assets necessary for livelihoods and in public spending on economic and social infrastructure and services. Research on conflict has emphasized ethnicity, religion, linguistic differences, tribal affiliations, etc., as sources of conflict" (Murshed2007:5).

In a multi-ethnic and multi-religious society like Nigeria, therefore, feeling and reality of relative deprivation may exist and engender conflicts.

In this study, the respondents were asked, "Thinking of the most violent conflict in your city since the return to civil rule in 1999, what was the conflict about?" The major violent conflicts that occurred in the eleven cities were classified as religious, electoral, ethnic, economic and communal by the respondents (Fig 1 and table 4). Inter-religious and election-related violence were the most prevalent forms of conflict recorded (fig. $1)$.

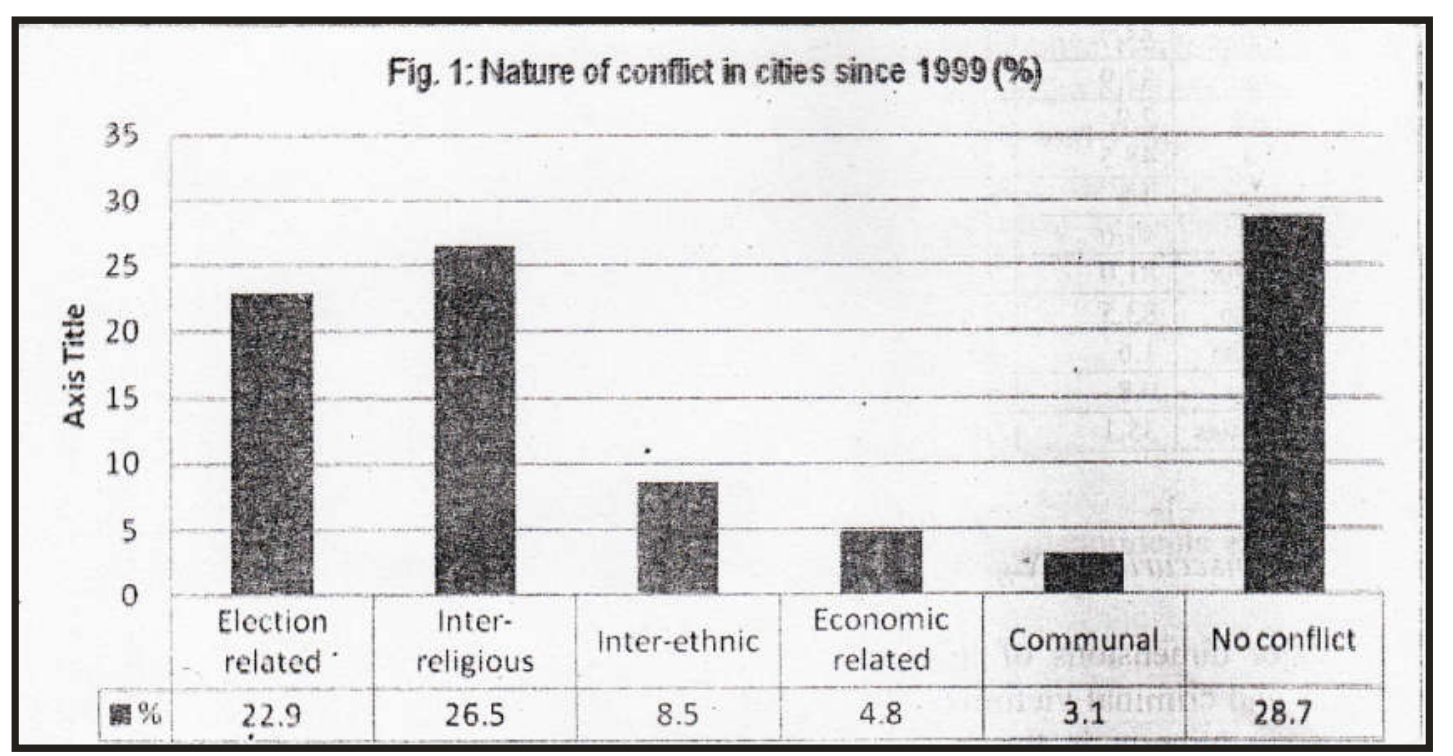

Election-related conflict was prevalent in Ibadan; JQS, Jfauchi, Eriugu and Lafia while inter-religious conflict was prevalent in Kaouna. Jos, BaHchi, Sbkote-and Kano. There 
were more reports of ethnic conflict recorded in Lafia, Kaduna and Kano (all in the northern part of the country) than in other cities (table 3 ).

Table 3: Nature of Conflict in Cities Since 1999

\begin{tabular}{|c|c|c|c|c|c|c|}
\hline \multirow[t]{2}{*}{ Cities } & \multicolumn{6}{|c|}{ Nature of conflict } \\
\hline & $\begin{array}{l}\text { Election } \\
\text { related }\end{array}$ & $\begin{array}{l}\text { Inter- } \\
\text { religious }\end{array}$ & Inter-ethnic & $\begin{array}{l}\text { Economic } \\
\text { related }\end{array}$ & $\begin{array}{l}\text { Intra- } \\
\text { communal }\end{array}$ & $\begin{array}{r}\text { No } \\
\text { conflict }\end{array}$ \\
\hline Enugu & 25.6 & 9.6 & 4.8 & 6.4 & 2.0 & 50.0 \\
\hline Kaduna & 8.4 & 61.2 & 14.0 & 3.2 & 1.2 & 7.2 \\
\hline Kano & 16.8 & 24.0 & 12.4 & 3.2 & 3.2 & 38.4 \\
\hline Lagos & 18.0 & 17.6 & 9.6 & 5.2 & 6.4 & 31.2 \\
\hline Lafia & 25.2 & 17.6 & 21.8 & 7.2 & 2.4 & 23.2 \\
\hline Ibadan & 41.2 & 0.0 & 2.4 & 6,4 & 9.8 & 27.2 \\
\hline Jos & 34.8 & 44.4 & 6.0 & 4.0 & 3.6 & 0.8 \\
\hline Bauclii & 29.2 & 53.2 & 6.8 & 5.6 & 1.2 & 1.2 \\
\hline Sokoto & 20.8 & 30.4 & 2.0 & 2.4 & 0.8 & 34.4 \\
\hline Onitsha & 18.0 & 16.0 & 8.4 & 2.8 & 2.0 & 51.6 \\
\hline Aba & 14.4 & 17.2 & 5.6 & 6.4 & 2.0 & 50.8 \\
\hline All cities & 22.9 & 26.5 & 8.5 & 4.8 & 3.1 & 28.7 \\
\hline
\end{tabular}

\section{Frequency of Violent Ethnic and Religious Conflicts}

Ethnic and religious conflicts are becoming endemic in cities like Kaduna, Jos, Kano and Bauchi where repeated occurrences of ethno-religious violence have taken place. The responses shown in table 4 reveal that Ibadan was the city with the least incidence of ethnic and religious violence that led to loss of lives. This is in congruence with the responses of the respondents from the city indicating electionrelated violence as the most prevalent form of conflict. Sokoto, which has a high Muslim population, has the least incidence of inter-ethnic violence. The data presented in table 4 indicate that since 1999, ethnic conflicts were more frequent in Kaduna, Bauchi, Onitsha, Jos, Enugu and Lagos. Similarly religious conflicts resulting in loss of lives were more frequent in Bauchi, Kaduna, Jos and Onitsha (table 4). Religious conflicts in the Eastern cities like Onitsha and Enugu were generally between Christian groups or between Christians and traditional religion adherents. The high frequencies of ethnic and religious conflicts reported in Kaduna has to do with the difficulty of separating ethnic and religious conflicts in most cities because of the high contingency of ethnicity and religion among the residents. 
Table 4: Frequency of Ethnic and Religious Conflicts Resulting in the Loss of Life

\begin{tabular}{|c|c|c|c|c|c|c|}
\hline \multirow[t]{2}{*}{ Cities } & \multicolumn{3}{|c|}{$\begin{array}{l}\text { Ethnic conflicts resulting in loss } \\
\text { of life }\end{array}$} & \multicolumn{3}{|c|}{$\begin{array}{l}\text { Religious conflict resulting in loss } \\
\text { of life }\end{array}$} \\
\hline & None & Once & $\begin{array}{l}\text { Twice } \\
\text { and more }\end{array}$ & None & Once & $\begin{array}{l}\text { Twice and } \\
\text { More }\end{array}$ \\
\hline Enugu & 18.4 & 12,0 & 69.6 & 28.0 & 8.0 & 64.0 \\
\hline Kaduna & 4.1 & 9.1 & 83.2 & 1.4 & 5.9 & 90.4 \\
\hline Kano & 11.4 & 29.5 & 55.0 & 6.7 & 43.0 & 47.7 \\
\hline Lagos & 21.8 & 8.8 & 68.4 & 25.2 & 7.5 & 64.0 \\
\hline Nasarawa & 13.4 & 21.0 & 64.5 & 30.6 & 8.6 & 59.6 \\
\hline Ibadan & 67.2 & 9.6 & 18.7 & 86.4 & 4.0 & 4.0 \\
\hline Plateau & 20.1 & 2.1 & 71.8 & 0.9 & 3.8 & 84.0 \\
\hline Bauchi & 3.3 & 8.3 & 82.3 & 0.4 & 5.4 & 91.4 \\
\hline Sokoto & 43.3 & 18.4 & 30.4 & 22.0 & 24.1 & 47.4 \\
\hline Onitsha & 7.6 & 16.8 & 73.9 & 10.1 & 14.3 & 74.0 \\
\hline $\mathrm{Aba}$ & 27.1 & 11.9 & 60.1 & 16.9 & 22.0 & 61.0 \\
\hline All cities & 20.6 & 12.5 & 63.3 & 19.4 & 11.8 & 66.1 \\
\hline
\end{tabular}

Violence can become a culture in some circumstances. Wolfgang and Ferracutti (1967) argued that a culture of violence develops and persists because a group of people condone and even encourage the use of violence in social interactipn. In view of the pervasive violent conflicts and crime in Nigeria, is a culture of violence developing in the country? Respondents were asked whether they "think the use of violence is acceptable" or whether "non-violence is always better" in certain situations. More than one tenth of the respondents said violence was most acceptable to (a) defend personal house and property; (b) defend a person's business or job; (c) defend a person's personal safety; (d) protect one's community, and (e) strongly protest an injury (fig. 3).

There are differences in the support for the use of violence among respondents in the different cities as shown in table 5:

a. More than one-fifth of the respondents in Kano, Lafia, Jos, Onitsha, and Aba said the use of violence was most acceptable in defending personal house and property.

b. About one-sixth of the respondents in Lafia, Enugu, Kano, Jos, Onitsha and Aba were of the opinion that violence was most acceptable in defending a person's job or business.

c. About one-fifth of the respondents in Kaduna, Lafia, Ibadan, Sokoto and Onitsha said it was most acceptable to use violence to defend one's personal safety.

d. More than one sixth of the respondents in Kano, Jos, Onitsha and Aba considered violence as the most acceptable means of defending or protecting one's community.

e. One-sixth of the respondents in Bauchi and Aba said violence was most acceptable in protesting an injury.

28 Annals of the Social Science Academy of Nigeria, No 20, 2015 
Fig. 3: Situations where violence is most acceptable $\{\%\}$

\section{7}

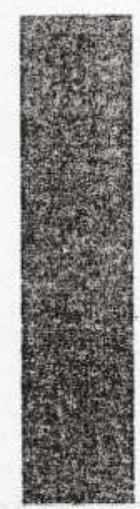

To defend personal house
18.7

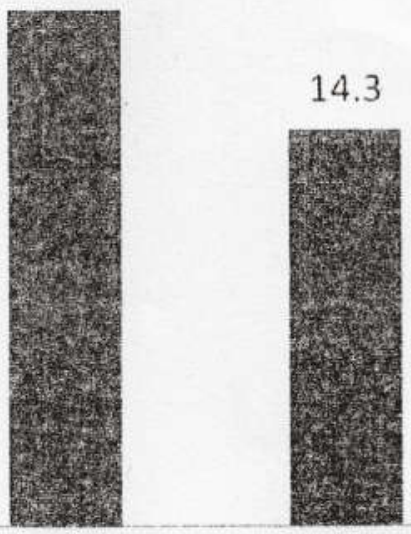

13.2

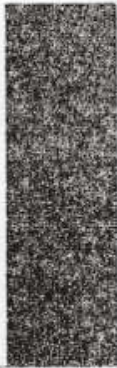

To strongly person's community protest an injury

and property business or job personal safety

Notwithstanding the significant support for the use of violence, majority of the respondents said that non-violence is always better in defending $a$ person's house and property (51.9\%); a person's business or job (55.9\%); a person's personal safety $(54.8 \%)$; one's community $(61.9 \%)$ and an injury $(60.8 \%)$.

Table 5: Acceptability of Violence in Defending Personal Safety, Possession and Community

Cities $\quad \%$ that responded that violence was most acceptable by context

$\begin{array}{lllcr}\begin{array}{l}\text { Defend personal } \\ \text { house and } \\ \text { property }\end{array} & \begin{array}{l}\text { Defend a } \\ \text { person's } \\ \text { business of } \\ \text { job }\end{array} & \begin{array}{l}\text { Defend a } \\ \text { person's } \\ \text { personal } \\ \text { safety }\end{array} & \begin{array}{l}\text { Protect } \\ \text { one's } \\ \text { Community }\end{array} & \begin{array}{l}\text { Strongly } \\ \text { protest } \\ \text { an injury }\end{array} \\ 16.0 & 16.4 & 14.0 & 9.8 & 10.0 \\ 16.8 & 15.2 & 18.8 & 15.6 & 10.0 \\ 25.6 & 16.4 & 17.6 & 18.8 & 14.0 \\ 15.6 & 13.6 & 16.4 & 10.4 & 11.2 \\ 20.8 & 18.4 & 19.6 & 12.0 & 9.6 \\ 13.6 & 12.6 & 27.6 & 13.2 & 14.0 \\ 21.6 & 16.0 & 17.6 & 17.2 & 14.8 \\ 7.2 & 15.2 & 14.0 & 12.4 & 17.2 \\ 11.6 & 15.2 & 19.5 & 12.8 & 12.0 \\ 23.2 & 17.2 & 22.8 & 16.8 & 18.0 \\ 23.2 & 16.8 & 17.2 & 18.0 & 13.2 \\ 17.7 & 15.7 & 18.7 & 14.3 & \end{array}$


Inter-group conflict in Nigeria may be attributed to several factors: colonial legacy of fragmentation and divide and rule; bad governance; poor economic performance due to mismanagement and corruption; non-realization of the promises and expectation of political independence form colonial rule. According to Ade Ajayi, Nigerians expected independence from colonial rule to produce concrete benefits for them, in the following:

Freedom from unjust and incomprehensible laws and directives; return of their land, and freedom to be left alone to live their lives and seek their own goals ... improved standards of living in housing and clothing, greater returns to their labor, better transportation ... education as a means to the social mobility that would ensure better life for their children, arid adequate water supply, electricity, health-care facilities and other such amenities of life (cited in Nzogonla-Ntalaja (1987: 76-77).

The expectations were not only legitimate but were rooted in the promises and political rhetoric of post-colonial Nigerian rulers to 'create' a better life for every Nigerian. But instead of fulfilling their promise of 'better life' for the citizens, the rulers subjected them to 'bitter life experiences.' Thus, rather than serve the people, Nigerian rulers military and civilian politicians alike - "vied with each other to acquire power and wealth as well as to do everything possible to retain ,hem." Consequently, "a very limited supply of government energy and resources" were 'made available for development purposes' (Nzongola-Ntalaja 1987:77) and to provide for the need of the citizens.

The insecurity generated by the failure, actions and in-actions of the rulers drove Nigerians from the national space to their respective primordial enclaves where they felt more secure and protected. The primordial identities and enclaves also provided them with a platform to reorganize and launch an attack on the insensitive and ineffective state. Identity politics also had its roots in the colonial amalgamation of different nationalities. Because of this, electoral politics, since the colonial era, has witnessed the use of ethnicity and religion as a means of excluding 'alien political parties' from the regions. Another source of exclusion based on ethnicity and religion was the colonial legacy of residential segregation of the 'strangers and pagans' from the Muslims in northern cities. Similarly, missionaries were compelled by the colonial government to settle outside the city inhabited by the Muslim indigenes in the northern territories (Crampton 1975).

In the midst of conflicts in the cities, what is the nature of the relationships between the ethnic and religious groups? Inter-group relations were cordial in some cities and antagonistic in others. More than three-quarters of the respondents in Ibadan said that cordial relationships existed between the ethnic and religious groups. This is in congruence with the responses that election-related conflicts were the most prevalent in the city (table 3). Electoral conflicts are more fluid than skirmishes along categorical 
identity politics and related violence such as ethnic and religious conflicts. Ibadan has no record of persistent ethnic or religious conflict. More than one-half of the respondents in Lagos, Aba, Kano and Sokoto reported cordial relationships between ethnic and religious groups in $\mathrm{u}$; e cities. Antagonistic relationship between ethnic and religious groups was reported in Jos, Kaduna and Bauchi. These cities have witnessed several ethno-religious conflicts since 1999 (fig.4).

Fig. 4: Existence of cordial relationship between ethnic and religious groups in selected cities (\%)

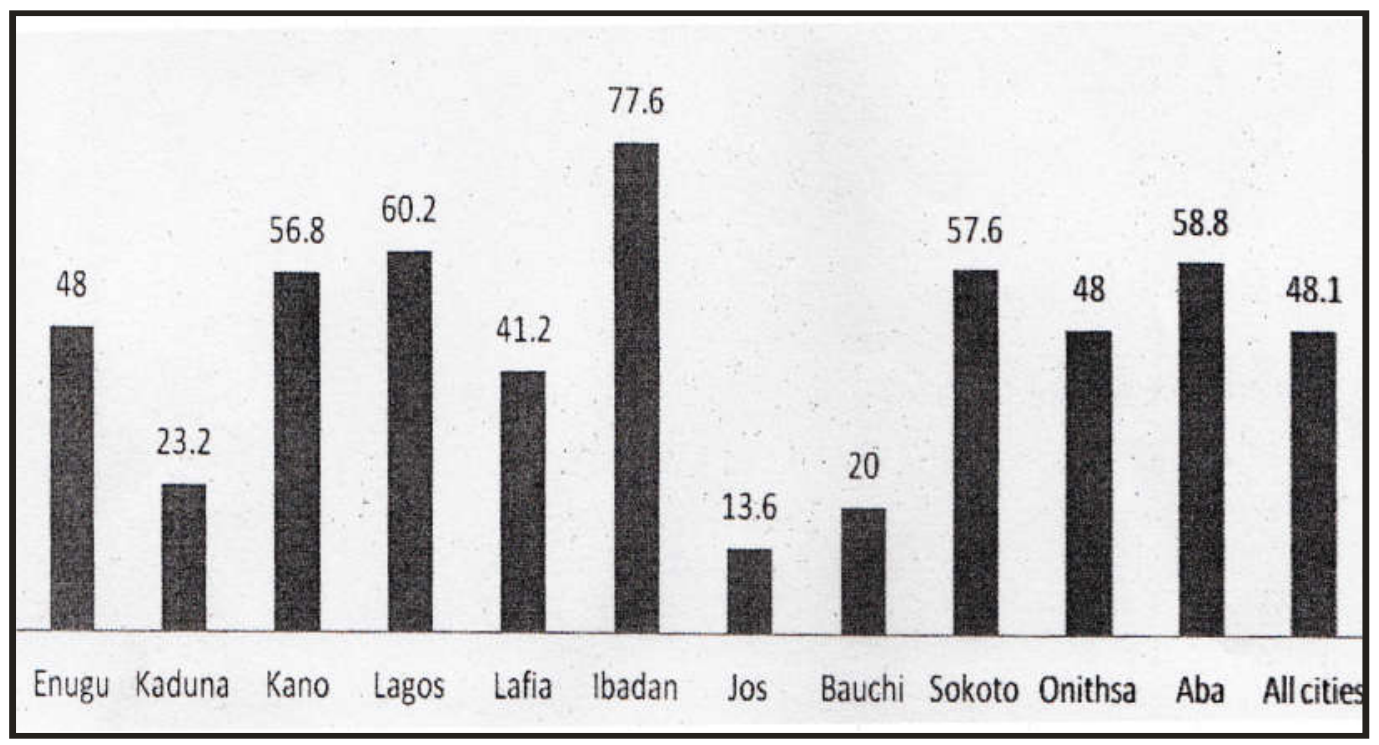

\section{Criminal Victimization and Feeling of Safety}

Violent crimes, especially armed robbery, have been a major crime problem encountered by Nigeria since the 1970s, after the end of the civil war. The repressive and law enforcement measures that have been employed by successive government have not been effective in tackling the problem of armed robbery in the country. Based on this, the respondents were asked, "In the past 2 years, have you or anyone in your household been the victim of a crime?" One-quarter of the respondents in the sample said that they or a member or members of their household had been victim of a crime in the past two years. The extent of victimization, however, varied across the cities as reflected in fig 5 . Criminal victimization was highest in Lagos, Jos, Kaduna and Onitsha and lowest in Ibadan and Kano. 
Fig. 5: \%of household members that experienced criminal victimization in the past two year

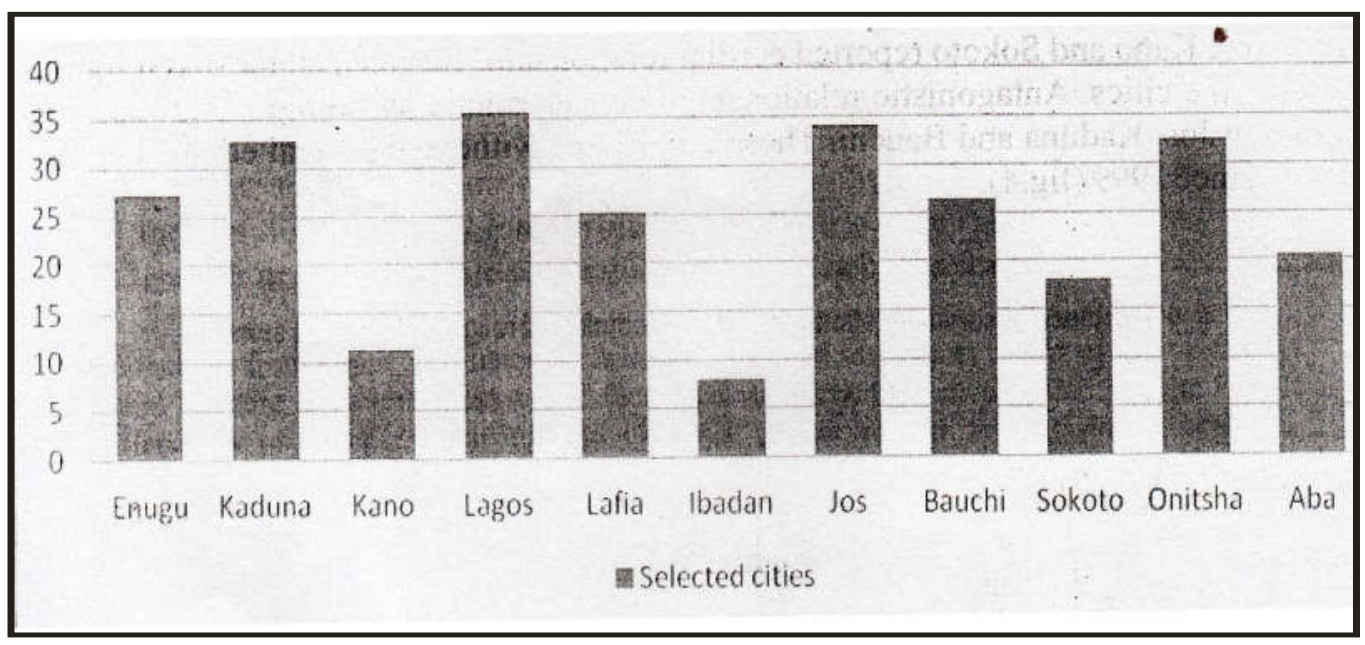

Different crime and disorder problems were observed in the different cities. Respondents were asked what they "think is the most common crime or disorder problem "in their community". Armed robbery and robbery were the major crime and disorder problem identified in majority of the cities (fig. 6).

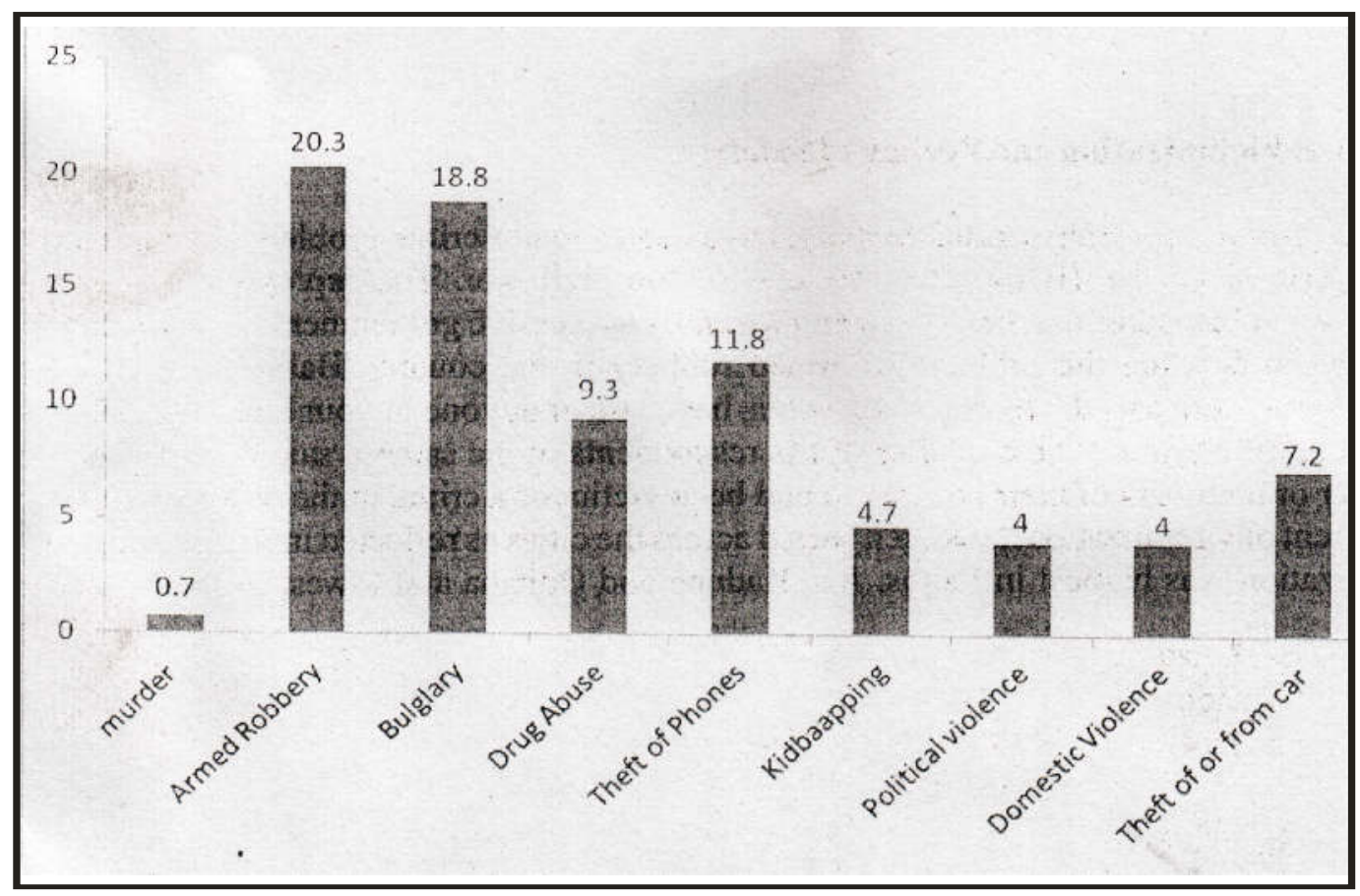

Armed robbery was a major problem in Aba, Onitsha, Lagos, Lafia and Kaduna. The use of vigilante to police the community gained attention after return to civil rule in

32 Annals of the Social Science Academy of Nigeria, No.20, 2015 
1999. One of the earliest well-known vigilante group specifically established to protect communities was the Bakassi boys, which was established by traders in $^{\wedge} \mathrm{Aba}$. The activities of the vigilante later spread from Aba in Abia State to other cities, including Onitsha, in the eastern part of the country. Burglary was a major crime problem in Lafia, Jos, Lagos, Kaduna, Sokoto, Bauchi and Enugu. Respondents in Kano, Bauchi, Sokoto and Jos identified drug abuse as a major problem in their cities. Kidnapping was a major problem in Aba while political violence was a concern in Kano and Ibadan (table 6).

Table 6: Most Common Crimes or Social Disorder related Problem in Community

\begin{tabular}{|c|c|c|c|c|c|c|c|c|c|}
\hline \multirow[t]{2}{*}{ Cities } & \multicolumn{9}{|c|}{ Crime and Social Disorder Related Problems } \\
\hline & Murder & $\begin{array}{c}\text { Armed } \\
\text { robber } \\
\mathrm{y}\end{array}$ & $\begin{array}{l}\text { Burgldr } \\
\mathrm{y}\end{array}$ & $\begin{array}{l}\text { Drug } \\
\text { Abup } \\
\mathrm{e}\end{array}$ & $\begin{array}{l}\text { Theft } \\
\text { of } \\
\text { Phonds }\end{array}$ & $\begin{array}{l}\text { Kidnap } \\
\text { ping }\end{array}$ & $\begin{array}{l}\text { Politic } \\
\text { violen }\end{array}$ & $\begin{array}{l}\text { Domestic } \\
\text { violende }\end{array}$ & $\begin{array}{l}\text { Theft } \\
\text { of or } \\
\text { from } \\
\text { car }\end{array}$ \\
\hline Enugu & 0.8 & 20.0 & 18.0 & 0.8 & 22.8 & 4.0 & 0.8 & 2.8 & 14.4 \\
\hline Kaduna & 0.8 & 24.8 & 22.8 & 13.6 & 6.4 & 2.4 & 1.6 & 2.4 & 7.2 \\
\hline Kano & 1.2 & 10.8 & 8.4 & 21.2 & 15.2 & 2.8 & 12.4 & 8.8 & 2.8 \\
\hline Lagos & 0.4 & 30.0 & 23.6 & 3.2 & 6.8 & 2.4 & 2.8 & 5.6 & 8.4 \\
\hline Lafia & 0.4 & 26.4 & 33.2 & 1.6 & 6.8 & 2.4 & 4.0 & 3.2 & 10.4 \\
\hline Ibadan & 0.0 & 8.8 & 8.0 & 3.2 & 18.8 & 0.8 & 12.8 & 6.4 & 2.0 \\
\hline Jos & 1.2 & 16.4 & 30.4 & 17.6 & 6.0 & 1.2 & 2.8 & 4.8 & 6.4 \\
\hline Bauchi & 1.2 & 5.6 & 18.4 & 20.8 & 11.6 & 2.4 & 4.0 & 7.6 & 3.2 \\
\hline Sokoto & 1.2 & 10.8 & 20.0 & 18.0 & 16.4 & 0.4 & 2.4 & 0.8 & 8.8 \\
\hline Onitsha & 0.0 & 30.8 & 12.0 & 1.6 & 15.6 & 2.0 & 0.4 & 1.2 & 10.8 \\
\hline $\mathrm{Aba}$ & 0.0 & 38.4 & 12.4 & 1.2 & 3.2 & 30.8 & 0.4 & 0.0 & 4.8 \\
\hline All cities & 0.7 & 20.3 & 18.8 & 9.3 & 11.8 & 4.7 & 4.0 & 4.0 & 7.2 \\
\hline
\end{tabular}

The respondents were asked about the most common crime and disorder problem in their cities and their states. In some cases, the respondents felt that certain crime constituted a greater problem in the state than in their communities, while in other cases, the communities were considered more insecure in terms of the prevalence of some crimes (fig 7). Serious crimes like murder, armed robbery, kidnapping and political violence were seen as more of a problem at the state level than burglary, drug abuse, theft of mobile phone handset and theft of or from car were perceived as more prevalent crime problem in their communities. Serious crimes receive greater media publicity and, create fear among citizens. These may be responsible for the greater awareness and perception of serious crimes being more prevalent in the state than in the communities of the respondents. 
Rg. 7: Comparison of most common disorder problems in states and cities

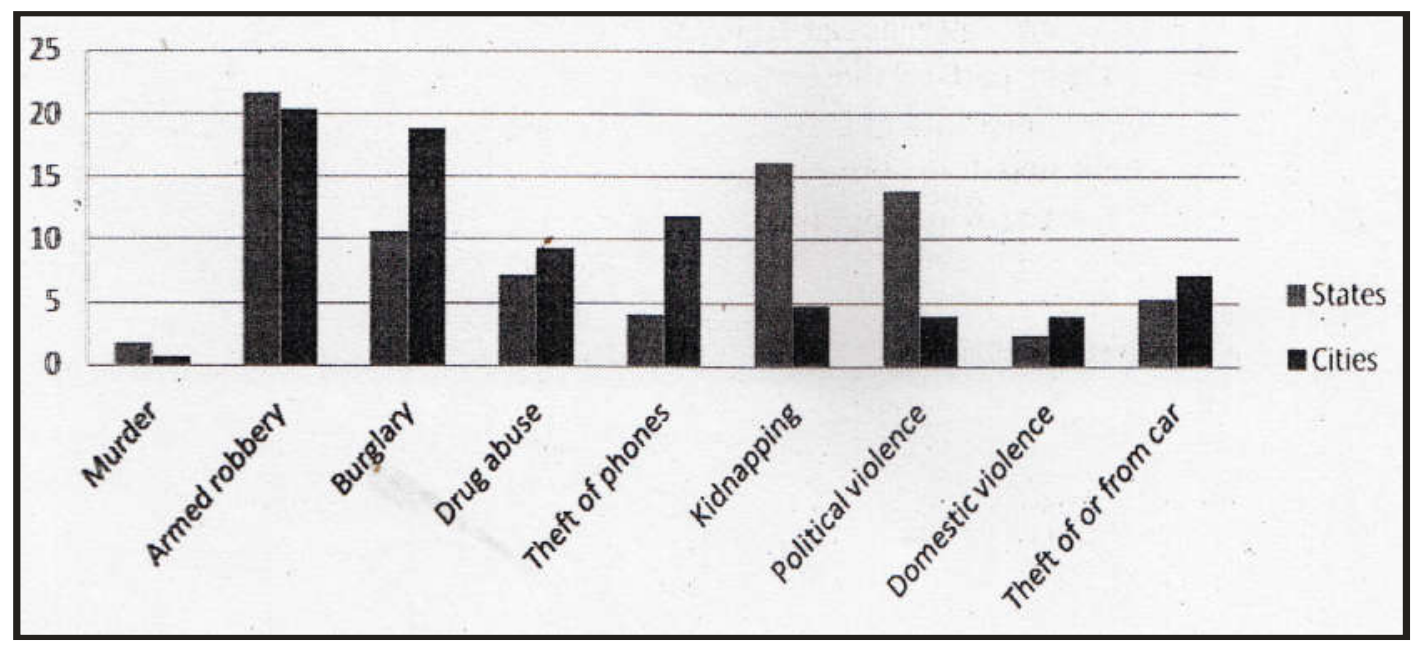

Fear of crime can be paralysing and inhibitive of both individual and collective social, economic and political relations and activities. On the basis of this, the respondents were asked, "Looking at the situation in Nigeria today, how safe or unsafe would you feel in the following situations?" The situations were meeting strangers, meeting policemen, attending events or meetings; going to polling station during an election; wearing a political party T-shirt, and attending political rallies. These are the things (with the exception of meeting strangers) that citizens in democratic societies are expected to feel free to do. However, in the case of Nigeria, the data showed that citizens feel generally insecure in doing so (fig 8).

Fig. 8: \% of respondents that felt unsafe (somewhat/very unsafe)

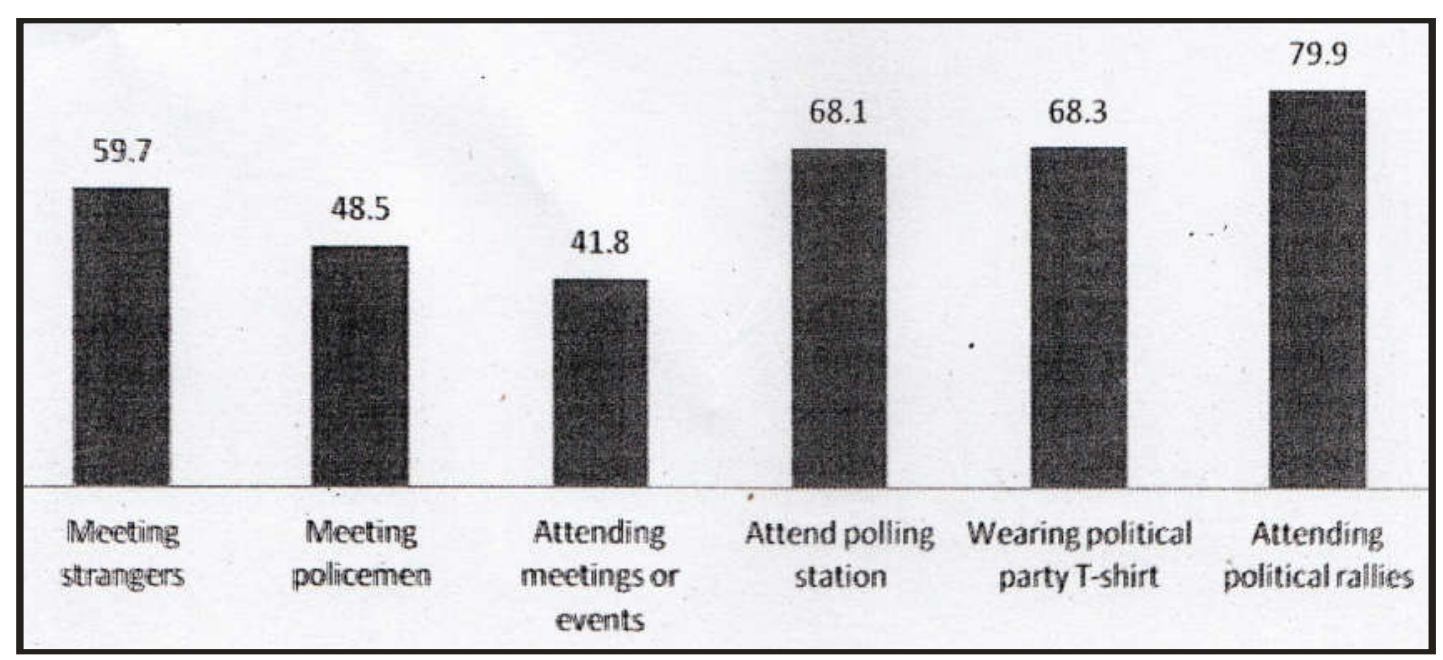

The data showed that the respondents felt more secure meeting a stranger than meeting a policeman or participating in activities that are elements of democratic culture. There were variations in the feeling of insecurity among respondents across the cities. Fear of 
meeting strangers was highest in Jos and Bauchi where there have been repeated violent conflicts since 1999. Fear of meeting policemen was highest in Lagos, Jos and Aba. More than one-half of respondents in Jos, Kano and Lafia felt insecure attending meetings and events (table 7).

Table 7: Feeling of Safety in Nigerian Cities by Residents

\begin{tabular}{|l|l|l|l|l|l|l|}
\hline Cities & \multicolumn{2}{|c|}{$\%$ that felt somewhat unsafe /very unsafe by context } \\
\hline & $\begin{array}{l}\text { Meeting } \\
\text { Strangers }\end{array}$ & $\begin{array}{l}\text { Meeting } \\
\text { Policemen }\end{array}$ & $\begin{array}{c}\text { Attending } \\
\text { meetings } \\
\text { or events }\end{array}$ & $\begin{array}{c}\text { Attend } \\
\text { polling } \\
\text { station } \\
\text {-shirt }\end{array}$ & $\begin{array}{c}\text { Wearing } \\
\text { political } \\
\text { party T }\end{array}$ & $\begin{array}{c}\text { Attending } \\
\text { political } \\
\text { rallies }\end{array}$ \\
\hline Enugu & 60.8 & 44.4 & 46.0 & 78.4 & 62.8 & 81.6 \\
\hline Kaduna & 64.4 & 50.0 & 48.0 & 78.0 & 70.8 & 80.4 \\
\hline Kano & 54.8 & 34.4 & 52.0 & 68.4 & 64.0 & 84.0 \\
\hline Lagos & 59.2 & 60.4 & 46.4 & 64.8 & 66.8 & 74.8 \\
\hline Lafia & 64.0 & 47.2 & 50.8 & 68.8 & 77.2 & 86.4 \\
\hline Ibadan & 30.8 & 45.2 & 22.0 & 67.8 & 71.6 & 83.2 \\
\hline Jos & 74.0 & 60.4 & 53.6 & 68.4 & 65.6 & 79.2 \\
\hline Bauchi & 73.2 & 42.4 & 25.6 & 60.8 & 63.6 & 78.8 \\
\hline Sokoto & 55.6 & 34.8 & 33.6 & 57.2 & 89.6 & 90.8 \\
\hline Onitsha & 57.2 & 54.8 & 44.4 & 67.6 & 60.4 & 75.6 \\
\hline Aba & 62.4 & 59.6 & 37.2 & 69.2 & 59.2 & 73.6 \\
\hline All cities & 59.7 & 48.5 & 41.8 & 68.1 & 68.3 & 79.9 \\
\hline
\end{tabular}

Significant proportions of Nigerian citizens are afraid of participating in the democratic political process across the cities because of fear of violence in the electoral process (table 8).

\section{Effects of violent conflicts}

Violent conflicts in Nigeria had several negative consequences. More than a thousand people were killed in the conflicts that occurred in Jos in 2001 (Niki Tobi Judicial Commission Report 2002) and in Kaduna in 2002 (Judicial Commission Report), hundreds of people were also killed in the Boko Haram instigated conflicts in Bauchi, Maiduguri and Potiskum in 2009 (Internal Police Operational Report, 2009) and in Jos 2008 (Judicial Panel of Inquiry 2009). Respondents were asked about the most negative effects of conflicts in their cities. Their responses indicated that the most negative effects were homelessness (internal displacement); loss of job and decrease in employment opportunities; destruction of schools and educational facilities; increase in crime and higher prices of food (fig. 9). The poor are most affected by these effects of conflicts than their counterparts in the higher strata of society. 
fig. 9: \% of most negative effects of conflicts in the city

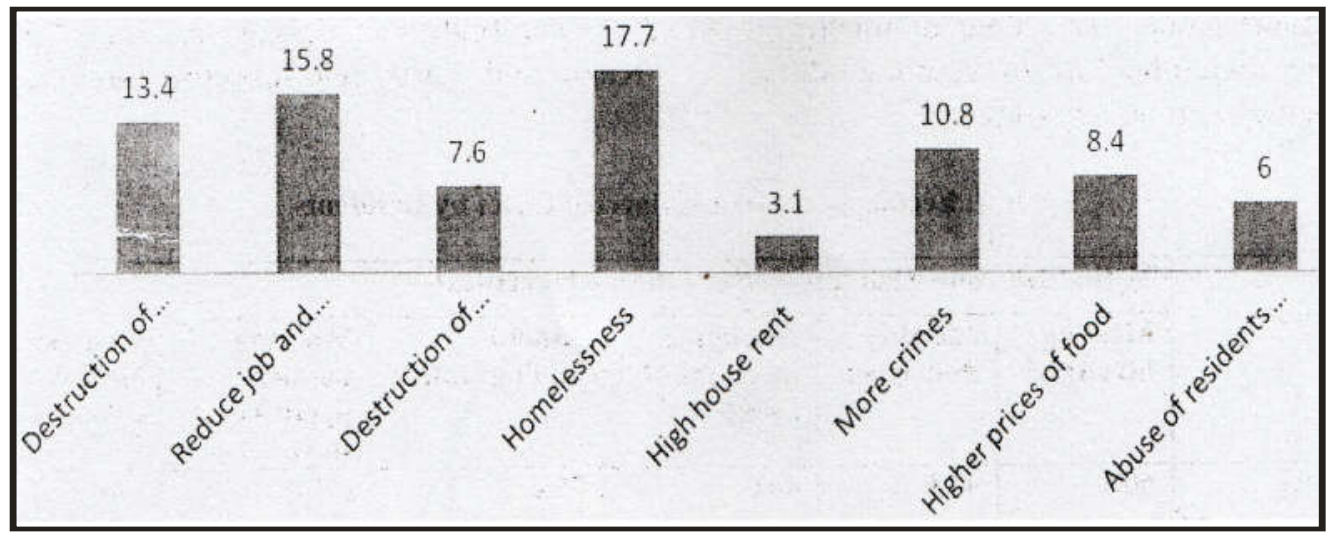

The effects of conflict vary across the cities (table 8). Destruction of schools and educational facilities were observed in Onitsha, Lafia, Aba, Enugu and Lagos. Loss of job and decease in employment opportunities were encountered after conflicts in Onitsha, Lagos, Lafia, Enugu, Aba and Jos. Residents of Kano, Bauchi, Sokoto, Jos and Kaduna experienced homelessness. During conflicts, people in danger, especially children, women and the poor run into safety in the stations and barracks of police, military and other security agencies. At the end of the conflict, the houses and property of many of the internally displaced persons would have been burnt, destroyed, or looted, rendering them homeless for a long period. Higher incidence of conflictinduced destruction of hospitals and health facilities was reported in Aba, Enugu and Onitsha (all in the eastern part of the country). Increased incidence of crime following conflict was more in Sokoto and Ibadan. High price of food and goods was recorded as one of the most negative consequences of conflict in Kano. Abuse of residents by security and law enforcement agencies was identified by $6 \%$ of the respondents as one of the most negative effects of conflicts (table 8).

Table 8: Most Negative Effects of Conflicts in City

\begin{tabular}{|c|c|c|c|c|c|c|c|c|}
\hline \multirow[t]{2}{*}{ Cities } & \multicolumn{8}{|c|}{$\%$ of respondents that identified the most negative effect of conflict } \\
\hline & $\begin{array}{l}\text { Destruct } \\
\text { ion of } \\
\text { schools }\end{array}$ & $\begin{array}{l}\text { Reduced } \\
\text { jobs and } \\
\text { employm. }\end{array}$ & $\begin{array}{l}\text { Destructi on } \\
\text { of } \\
\text { hospitals }\end{array}$ & $\begin{array}{l}\text { Home- } \\
\text { lessness }\end{array}$ & $\begin{array}{l}\text { High } \\
\text { prices of } \\
\text { house / rent }\end{array}$ & $\begin{array}{l}\text { More } \\
\text { crimes }\end{array}$ & $\begin{array}{l}\text { High } \\
\text { price of } \\
\text { food }\end{array}$ & $\begin{array}{l}\text { Abuse by } \\
\text { security } \\
\text { agencies }\end{array}$ \\
\hline Enugu & 23.1 & 21.5 & 14.0 & 9.9 & 3.3 & 8.3 & 5.0 & 7.4 \\
\hline Kaduna & 11.4 & 13.2 & 9.5 & 25.0 & 6.4 & 5.5 & 4.5 & 6.8 \\
\hline Kano & 2.0 & 4.7 & 0.7 & 30.2 & 5.4 & 10.1 & 30.9 & 6.7 \\
\hline Lagos & 19.0 & 26.8 & 9.9 & 9.9 & 2.1 & 7.0 & 2.8 & 8.5 \\
\hline Lafia & 24.9 & 23.2 & 9.7 & 7.6 & 4.3 & 5.9 & 6.5 & 1.1 \\
\hline Ibadan & 6.7 & 4.0 & 2.0 & 5.4 & 2.0 & 20.1 & 7.4 & 8.1 \\
\hline Jos & 14.2 & 18.9 & 8.6 & 25.3 & 1.7 & 3.4 & 10.3 & 1.3 \\
\hline Bauchi & 4.6 & 7.9 & 3.8 & 27.9 & 3.3 & 10.0 & 9.2 & 10.8 \\
\hline Sokoto & 2.8 & 12.8 & 2.8 & 25.5 & 2.1 & 39.0 & 5.0 & 2.8 \\
\hline Onitsha & 28.0 & 29.7 & 11.0 & 2.5 & 0.8 & 7.6 & 5.1 & 8.5 \\
\hline Aba & 20.2 & 19.9 & 14.9 & 6.1 & 0.0 & 9.6 & 4.4 & 5.3 \\
\hline All cities & 13.4 & 15.8 & 7.6 & 17.7 & 3.1 & 10.8 & 8.4 & 6.0 \\
\hline
\end{tabular}




\begin{tabular}{|l|l|l|l|l|l|l|l|l|}
\hline Jos & 14.2 & 18.9 & 8.6 & 25.3 & 1.7 & 3.4 & 10.3 & 1.3 \\
\hline Bauchi & 4.6 & 7.9 & 3.8 & 27.9 & 3.3 & 10.0 & 9.2 & 10.8 \\
\hline Sokoto & 2.8 & 12.8 & 2.8 & 25.5 & 2.1 & 39.0 & 5.0 & 2.8 \\
\hline Onitsha & 28.0 & 29.7 & 11.0 & 2.5 & 0.8 & 7.6 & 5.1 & 8.5 \\
\hline Aba & 20.2 & 19.9 & 14.9 & 6.1 & 0.0 & 9.6 & 4.4 & 5.3 \\
\hline All cities & 13.4 & 15.8 & 7.6 & 17.7 & 3.1 & 10.8 & 8.4 & 6.0 \\
\hline
\end{tabular}

\section{Citizens and the police}

The police are specialised state officials responsible for the prevention and investigation of crimes; detection, apprehension and prosecution of offenders; and assistance to citizens in security and safety distress. They are the gatekeepers to the criminal justice system and thereby play critical role in the extent to which the rule of law is observed and human rights are protected by the legal system. The police force in Nigeria was a colonial agency as it was established to protect the interest of the colonial power. Until now, the police in the country are generally regarded as government police rather than people's police (Alemika 1988, 1993, 2003b; Alemika and Chukwuma 2000; Ahire 1991; Odekunle 1979). They are generally perceived as inefficient, corrupt and uncivil (Alemika 1993; 2003). Responding to these problems, the federal Government established Presidential Police Reform Committees in 2006 and 2008 to study and make recommendations on the reform of the police in the country. The implementation of Reports has so far generally lacked any fundamental shifts in the organisation, management, operations, conduct, accountability and effectiveness of the police. There is a national police force called the Nigeria Police Force. Section 214 of the Constitution prohibits the establishment of other police forces at the national and sub-national levels.

In view of the pervasive conflicts in the country, we examined the citizens' perspective on the effectiveness of the police in conflict prevention and mitigation; citizens' trust in the police and satisfaction with police services as well as willingness to report crime to the police. The respondents were asked how effective they think the police have been in preventing conflicts or reduce the damage once they have started. The results show that they were generally perceived as ineffective (fig. 10). Only about a third of the sample thought that the police were sometimes or most often effective. 
Fig. 10: Effectiveness of the police in preventing or containing conflict (\%)

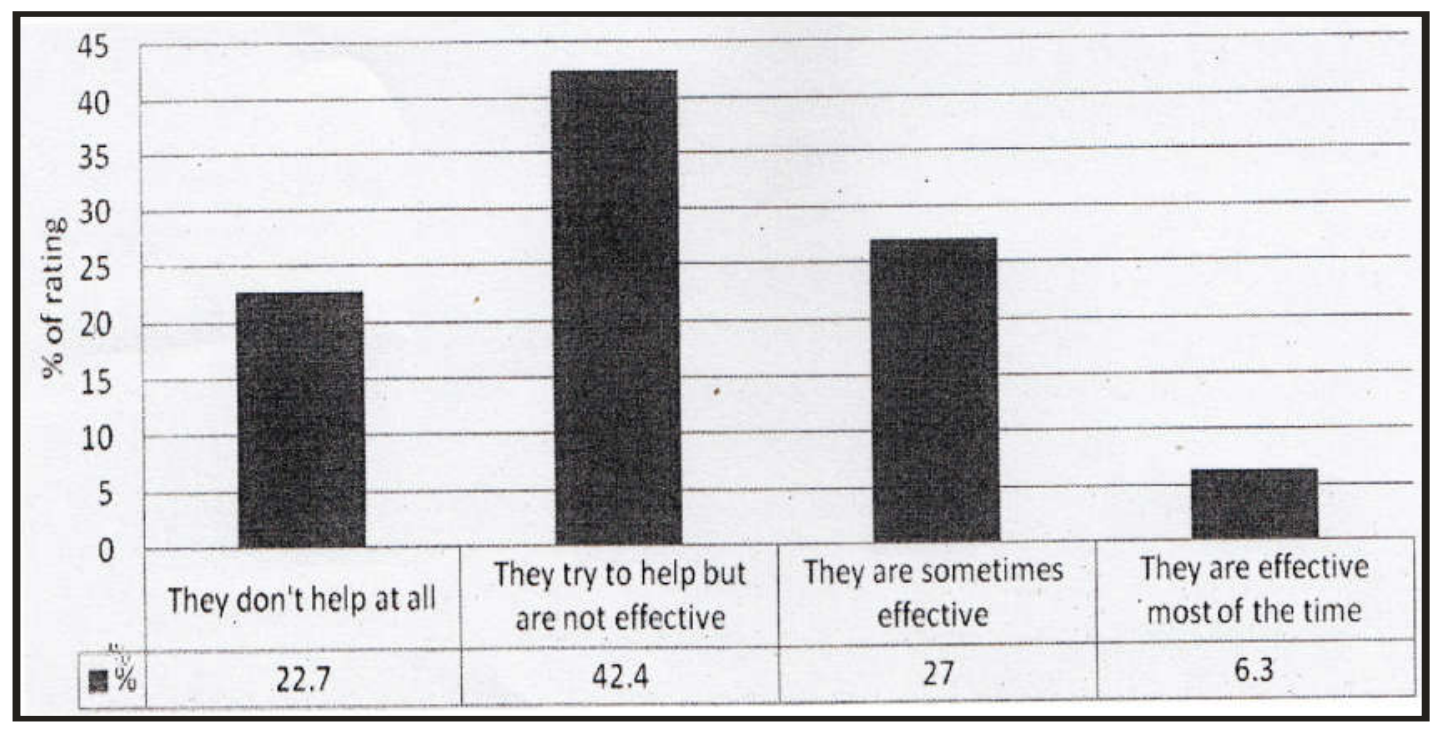

The perception of the level of effectiveness of the police in conflict prevention and mitigation varied among the residents in the eleven cities. More than two-fifths of the respondents in Kaduna, Enugu and Sokoto said the police were effective in preventing and containing conflicts. In contrast, less than a quarter of the respondents in Lagos and Kano (the two most populous states in the country) considered the police ineffective (table 9).

Table 9: Effectiveness of the Police in Preventing Or Containing Conflict

\begin{tabular}{|l|c|c|c|c|}
\hline \multirow{2}{*}{ Cities } & \multicolumn{4}{|c|}{ Effectiveness of police in conflict prevention and mitigation } \\
\cline { 2 - 5 } & $\cdots$ & $\begin{array}{c}\text { They try to } \\
\text { help but are } \\
\text { not effective }\end{array}$ & $\begin{array}{l}\text { They are } \\
\text { sometimes } \\
\text { effective }\end{array}$ & $\begin{array}{l}\text { They are } \\
\text { effective most } \\
\text { of the time }\end{array}$ \\
\hline Enugu & 14.9 & 38.8 & 37.2 & 9.1 \\
\hline Kaduna & 10.5 & 45.9 & 31.8 & 10.0 \\
\hline Kano & 26.8 & 50.3 & 8.7 & 12.1 \\
\hline Lagos & 37.3 & 38.0 & 21.1 & 2.1 \\
\hline Lafla & 21.6 & 46.5 & 24.9 & 4.9 \\
\hline Ibadan & 28.2 & 36.9 & 26.2 & 3.4 \\
\hline Jos & 25.9 & 45.1 & 24.9 & 5.0 \\
\hline Bauchi & 15.4 & 46.3 & 31.7 & 10.6 \\
\hline Sokoto & 12.1 & 42.6 & 31.2 & 3.4 \\
\hline Onitsha & 27.1 & 38.1 & 31.4 & 1.8 \\
\hline Aba & 43.0 & 25.4 & 28.1 & 6.3 \\
\hline All cities & 22.7 & 42.4 & 27.0 & \\
\hline
\end{tabular}

38 Annals of the Social Science Academy of Nigeria, No 20, 2015 
The literature indicates that trust in the police is related to their performance and conduct. The respondents were asked how much they trust the police. Less than a ifuarter of the respondents had trust in the police. More than two-fifths had no trust in the police at all (fig 11)

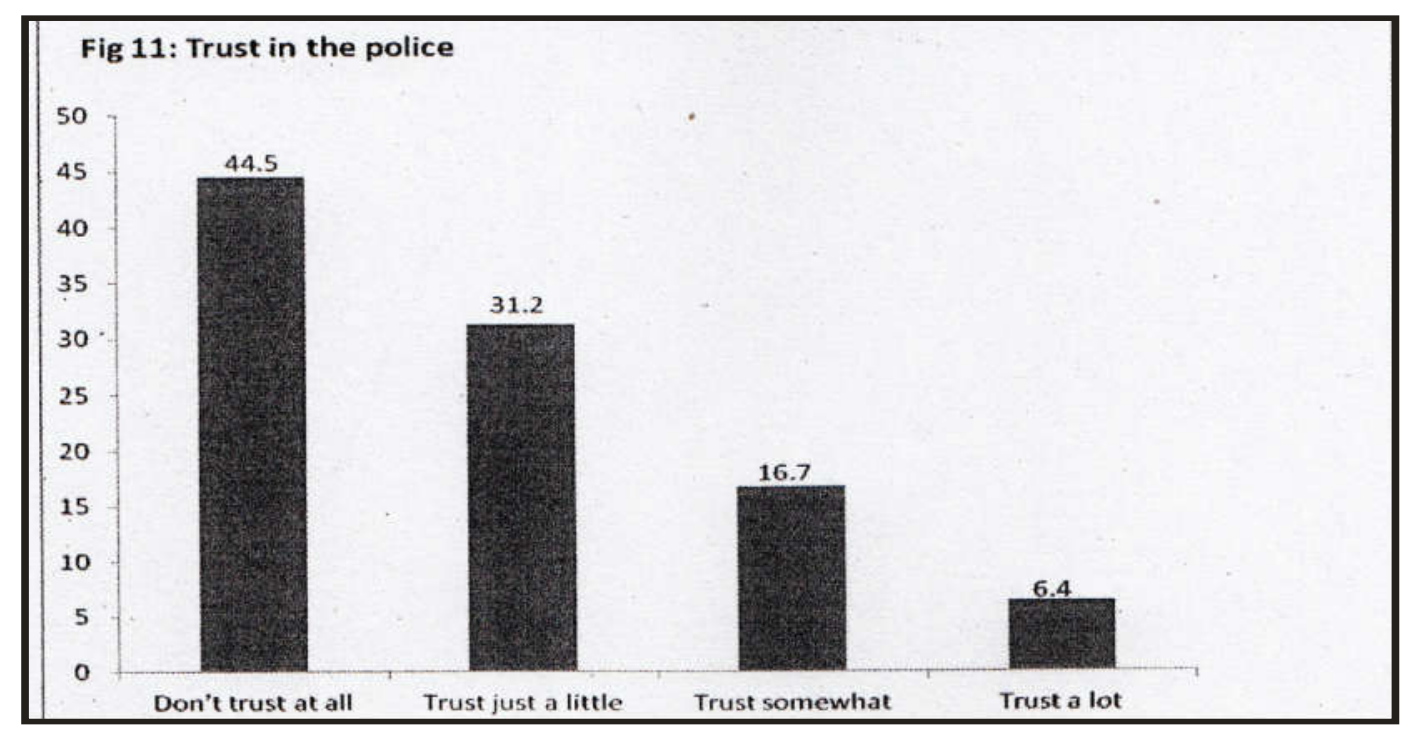

The level of trust in the police varied across the cities. More than one-half of the respondents in Kano trusted the police (table 10) despite their perception that the police are ineffective in preventing and mitigating conflicts (table 9). The police were generally distrusted by residents of Aba, Onitsha, Enugu, Lagos and Ibadan - all in the southern part of Nigeria (table 10).

Table 10: Trust in police

\begin{tabular}{|l|l|l|l|l|}
\hline \multirow{2}{*}{ Cities } & \multicolumn{2}{|c|}{ Trust in police } & \multicolumn{2}{|c|}{ Trust } \\
\cline { 2 - 5 } & $\begin{array}{l}\text { Don't } \\
\text { trust at all }\end{array}$ & $\begin{array}{l}\text { Trust just } \\
\text { a little } \\
\text { somewhat }\end{array}$ & lot \\
\hline Enugu & 41.2 & 39.6 & 13.6 & 5.6 \\
Kaduna & 33.2 & 38.0 & 20.8 & 6.8 \\
Klano & 17.2 & 31.6 & 32.8 & 17.6 \\
Lagos & 56.8 & 23.6 & 14.4 & 3.6 \\
Lafla & 42.0 & 34.0 & 17.2 & 6.4 \\
Ibadan & 58.4 & 28.0 & 10.8 & 2.4 \\
Jos & 38.4 & 38.0 & 14.8 & 7.2 \\
Bauchi & 40.0 & 40.0 & 11.2 & 8.4 \\
Sokoto & 36.4 & 27.2 & 23.2 & 9.6 \\
Onitsha & 54.8 & 26.4 & 15.6 & 2.0 \\
Aba & 71.6 & 16.4 & 8.8 & 1.2 \\
\hline
\end{tabular}

Satisfaction with the services of the police is generally a precondition for public cooperation with policemen and policewomen. Satisfaction broadly derives from the 
performance, conduct and integrity of the police. The level of satisfaction varied widely across the cities (table 11). More than one-half of the respondents in Kaduna, Kano, Lagos, Lafia, Jos. Bauchi and Sokoto were satisfied with police services. Less than a third (30\%) of the respondents in Aba were satisfied with police services.

Table 11: Satisfaction with Policing

\begin{tabular}{|l|l|l|l|l|}
\hline Cities & \multicolumn{3}{|c|}{ Satisfaction with policing } \\
\hline & $\begin{array}{l}\text { Very } \\
\text { satisfied }\end{array}$ & Satisfied & Unsatisfied & $\begin{array}{l}\text { Very } \\
\text { unsatisfied }\end{array}$ \\
\hline Enugu & 9.2 & 37.6 & 38.0 & 14.4 \\
Kaduna & 14.8 & 39.6 & 39.2 & 5.2 \\
Kano & 13.2 & 54.8 & 19.6 & 12.4 \\
Lagos & 17.6 & 32.4 & 29.2 & 20.4 \\
Lafia & 22.4 & 37.2 & 32.4 & 7.6 \\
Ibadan & 3.2 & 38.0 & 36.8 & 21.6 \\
Jos & 17.2 & 36.8 & 34.8 & 10.8 \\
Bauchi & 15.2 & 37.2 & 34.0 & 13.6 \\
Sokoto & 10.4 & 47.6 & 26.4 & 8.4 \\
Onitsha & 14.4 & 32.8 & 32.4 & 19.2 \\
Aba & 8.4 & 21.6 & 30.8 & 39.2 \\
All cities & 13.3 & 37.8 & 32.1 & 15.7 \\
& & & & \\
\hline
\end{tabular}

Slightly more than a half (51\%) of the respondents was dissatisfied with police performance. In contrast, $47.8 \%$ were satisfied with the level of performance by the police (fig. 12). Public trust and the assessment of performance reflect two different dimension of the overall legitimacy of the police. They respectively measure the integrity (conduct) and effectiveness.

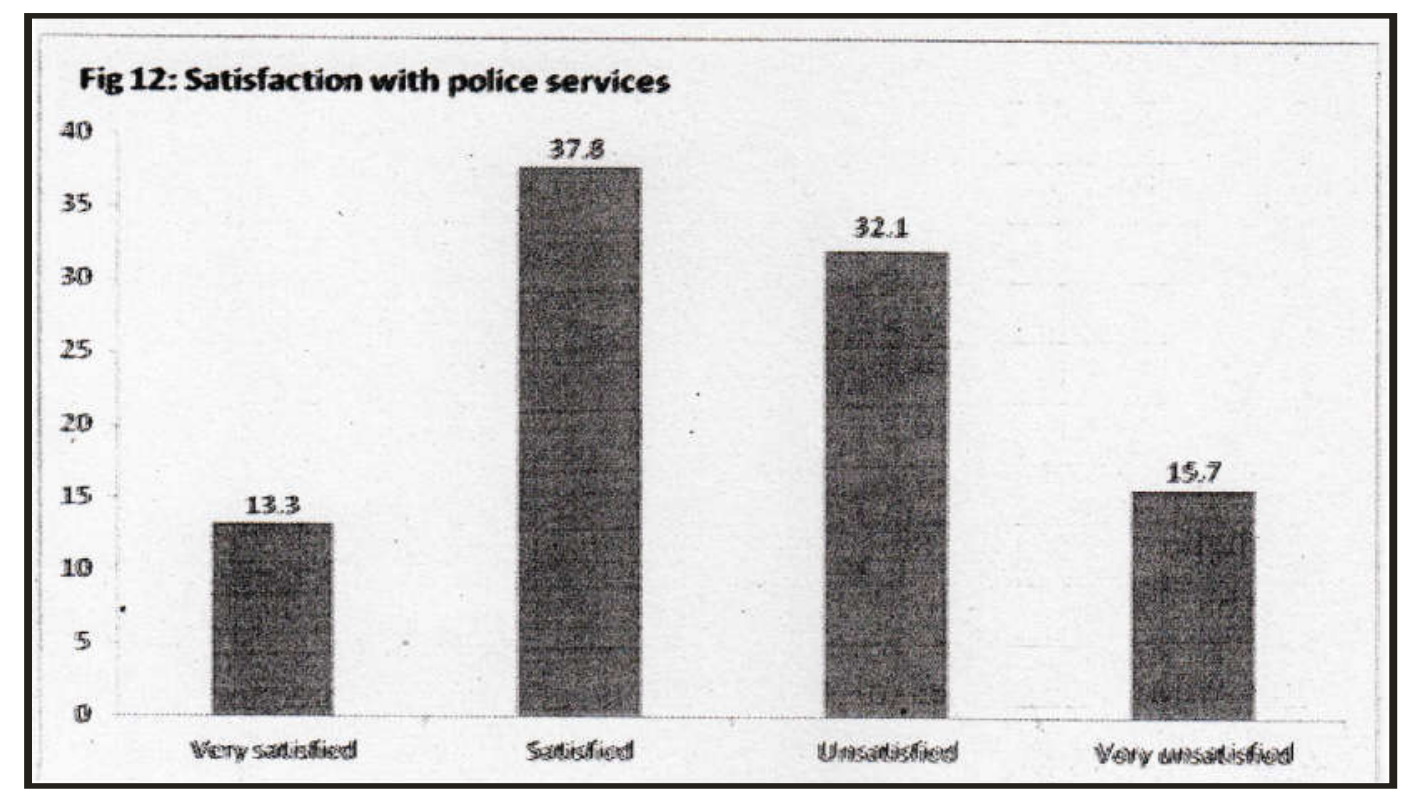

40 Annals of the Social Science Academy of Nigeria, No 20, 2015 
In the literature, trust in police and satisfaction with police services tend to influence the decisions of victims to report crime to the police. Therefore, we explored the relationship between satisfaction with police service and willingness to report crime to the police. Moderate positive relationship was observed between the two variables (with a bi-variate correlation of 0.297 ). The relationship between the two variables was relatively high in most cities, except Ibadan, Aba, Bauchi and Jos (fig 13).

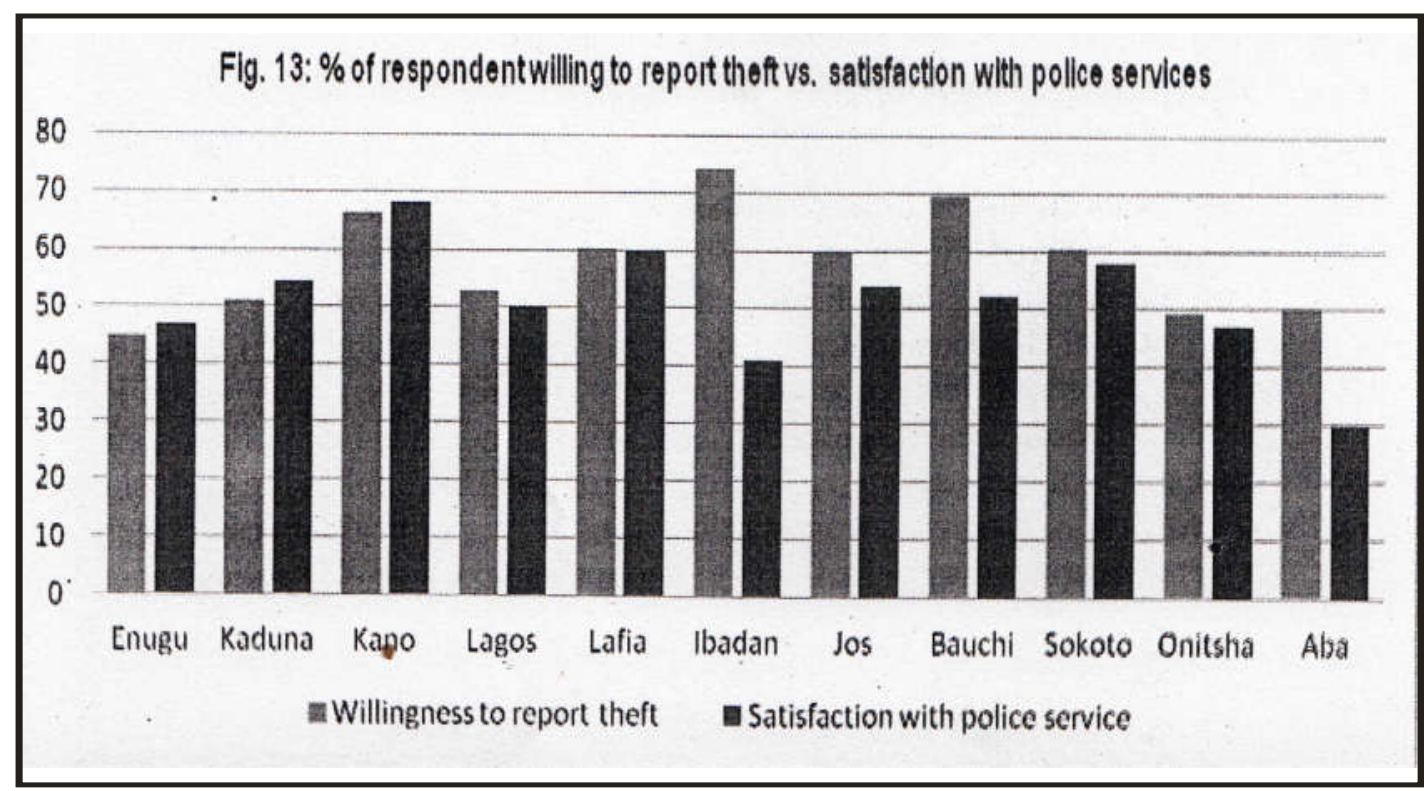

Conflicts in Nigeria derive from various sources and reflect the political, economic and social struggles and rivalries among the population. There is need for evidence-based and research-led policies for conflict prevention and mitigation.

\section{Summary of Major Findings}

The major findings of this study are:

> Prevalent forms of violent conflict in the cities were religious, electoral economic and ethnic;

$>$ Respondents from cities where frequents conflicts occurred tend to justify the use of violence to defend personal safety and property;

$>$ High proportion of respondents in Ibadan, Lagos, Sokoto and Aba reported cordial relationships between ethnic and religious group in the cities. Paradoxically, than one-half (56.8\%) of respondents in Kano known for frequent conflicts also reported the existence of cordial relationships between religious and ethnic groups in the city. Less than a quarter of residents of Jos, Bauchi and Kaduna, where frequent conflict had been recorded during the past three decades reported the existence of cordial relationships between ethnic and religious groups in the cities;

$>$ Less than a half(48.1) of the respondents in the sample across the cities reported cordial relationship between ethnic and religious groups;

$>$ Highest levels of criminal victimization of at least a household member were reported in Lagos, Jos, Kaduna and Onitsha, where $25-35 \%$ of the respondents reported that at least a member of their households was a victim of crime during the past two years; 
$>$ Armed robbery and burglary were the predominant crimes in the cities;

$>$ Respondents were generally fearful of attending polling station during elections, wearing Tshirt with the logo of political party and attending political rallies;

$>$ Police were perceived as ineffective in preventing and containing conflicts in cities, and

$>$ Most negative effects of conflicts experienced in the cities were homelessness, decrease in jobs and employment opportunities, destruction of schools, high prices of food and abuse of resident by security agencies.

\section{Conclusion}

We found that insecurity in the form of violent conflicts and crimes was widespread in the Nigerian cities covered by this study. The major sources of conflicts in the cities were religious, electoral and ethnic disputes and the major effects of the conflicts were homelessness (internal displacement, loss of employment, destruction of educational institutions and increased incidence of crimes). The respondents were afraid of attending political rallies, wearing political party t-shirts and attending polling stations. These are critical activities in democratic political process. This implies the exclusion of a significant proportion of citizens from participating in the political process. Nigerians in the cities were generally dissatisfied with the police and consider the police generally ineffective in mitigating violent conflicts. Armed robbery was reported by majority of the respondents as the most common crime and disorder problem in their community and states. It has been demonstrated in the literature that insecurity constitute constrain on economic growth and development, poverty reduction and consolidation of democracy in transitional societies. The findings provide information that can be used to formulate and implement policies that can mitigate insecurity and its effects in the country.

\section{References}

Albert, I. O. (1999) The Socio-Cultural Politics of Ethnic and Religious Conflicts, In Ernest E. Uwazie, Isaac O. Albert and Godfrey N. Uzoigwe, eds., Inter-Ethnic and Religious Conflict Resolution in Nigeria. New York: Lexington Books, 1999.

Alemika, E.E.O. (1993) Colonialism, State and Policing in Nigeria, Crime, Law and Social Change: An International Journal 20: 187-219.

Alemika, E.E.O. (2002) Sociological Analysis of Ethnic and Religious Conflicts in the Middle Belt of Nigeria. In EEO Alemika and F. Okoye, Eds. Ethno-Religious Conflicts and Democracy in Nigeria. Kaduna: Human Rights Monitor.

Alemika, E.E.O. (2003a) Protection of Minority Rights in a Democratic Nigerian Society" in N. Bagudu Ed. Linguistic Minorities and Inequality in Nigeria “ Jos: League of Human Rights.

Alemika, E.E.O. (2003b) Police Corruption and Insecurity in Nigeria, in S. Einstein and M. Amir (Eds.) Police Corruption: Paradigms, Models and concepts - Challenges for Developing 
Countries, Huntsville, Texas: Office of International Criminal Justice, Sam Houston State University, Chapter 18(445-494).

Alemika, E.E.O.(2004a) Poverty, Social Exclusion and Social Dislocation in Nigeria, pp. 110-124; D. A. Guobadia and E. Azinge Eds. Poverty, the Nigerian Economy and the Law. Lagos: Nigerian Institute of Advanced Legal Studies.

Alemika, E.E.O. (2004b) Prevalence, Sources and Resolution of Conflicts in Nigeria, In DA Bnggs, D.A. and Sanda, J.G (eds.) Issues of Peace and Security: Essays in Honour of Major-General Charles B. Ndiomu Kuru, Nigeria: National Institute, 147-164.

Alemika, E.E.O.(2004c) Ethnicity and Ethnic conflicts in Nigeria, Guobadia, D.A. and Adekunle, A.O. eds. Ethnicity and National Integration in Nigeria: Recurring Themes, Lagos: Nigerian Institute of Advanced Legal Studies, 87-108

Alemika, E.E.O. (2004d) Crime statistics and information management in Nigerian justice and security systems, In Alemika, E.E.O. and Chukwuma, I.C. (eds.) Crime and Policing in Nigeria: Challenges and Options, Lagos: Network on Police Reform in Nigeria (NOPRIN).

Alemika, E.E.O. (2005) Human Rights and Sharia Penal Code, In Alemika, E.E.O. and Okoye, P.O. eds. Human Rights and Sharia Penal Code in Northern Nigeria. Kaduna: Human Rights Monitor.

Alemika, E.E.O.(2007) The State and Religion in Nigeria, In Guobadia, DA and Azinge, E. eds. Current Themes in the 1999 Constitution: A Tribute to Hon. Justice SMA Belgore. Abuja: Nigerian Institute of Advanced Legal Studies, 56-79.

Alemika, E.E.O. (2010) Strategies for combating kidnapping in Nigeria. Paper presented at the Seminar on Kidnapping and National Security organized by the Alumni of the National Institute for Policy and Strategic Study, Koru in Collaboration with the Nigeria Police Force, on 12 $2^{\text {th }}$ August, 2010 at the Shehu Musa Yar'Adua Centre, Abuja.

Bach, D. (2005) Inching Towards a Country Without a State: Prebendalism, Violence and State Betrayal in Nigeria, In Clapham C, Herbst J and Mills, G. eds., Africa 's Big States, Johannesburg: Witwatersrand University Press.

Bach, D. (1997) Indigeneity, Ethnicity and Federalism, In Diamond, L., Kirk-Greene, A. and Oyediran, O. eds., Transition without End; Nigerian Politics and Civil Society under Babangida, Boulder: Lynne Rienner, 333350 .

Caldeira, P. R. 1996. Fortified enclaves: The new urban segregation, Public Culture 8: 303-328.

Centre for Law Enforcement Education \& Organisation Mondiale Centre la Torture, (2002) Hope Betrayed? A Report on Impunity and State-Sponsored Violence in Nigeria, Lagos \& Geneva: CLEEN \& OMCT.

Coser, L. (1967) Continuities in the Study of Social Conflict. New York: Free Press.

Crampton, E.P.T. (1975) Christianity and Northern Nigeria. London: Geoffrey Chapman. 
Fischer, C. (1975) Towards a sub-cultural theory of urbanism. American Journal of Sociology, 80: 1319-1341.

Howard, A.M. (2003) Cities in Africa, Past and Present: Contestation, Transformation, Discourse. Canadian Journal of African Studies, 37, No. 2/3: 197-235.

Human Rights Watch. (2005) Revenge in the Name of Religion: The Cycle of Violence in Plateau and Kano States. New York: Human Rights Watch.

Human Rights Watch. (2006) They Do Not Own This Place: Government Discrimination Against "NonIndigenes in Nigeria “. New York: Human Rights Watch.

Ibrahim, J. (2000) The Transformation of Ethno-Regional Identities in Nigeria, In Jega, A. (ed.) Identity Transformation and Identity Politics under Structural Adjustment in Nigeria (Uppsala: Nordiska Afrikainstitutet).

Jega, A. (2000) The State and Identity Transformation Under Structural Adjustment in Nigeria, In Jega, A. (ed.) Identity Transformation and Identity Politics under Structural Adjustment in Nigeria. (Uppsala: Nordiska Afrikainstitutet).

Kraxberger, B. (2005) Strangers, Indigenes and Settlers: Contested Geographies of Citizenship in Nigeria, Space and Polity, Vol. 9, No. 1:19.

Kukah, M. (1993) Religion, Politics and Power in Northern Nigeria (Ibadan: Spectrum Books). Ley, D. (1974). The black inner city as frontier outpost. Association of American Geographer Monograph 7, Washington D.C.

Louis Wirth (1938) Urbanism as a Way of Life, American Journal of Sociology, 44(1): 1-24.

Moser, C. O. N. (2004) Urban violence and insecurity: an introductory roadmap. Environment and Urbanization, Brief 10; 1-6.

Mu'azzam, I. And Ibrahim, J. (2000) Religious Identity in the Context of Structural Adjustment in Nigeria, In Jega, A. (ed.) Identity Transformation and Identity Politics under Structural Adjustment in Nigeria, Uppsala: Nordiska Afrikainstitutet.

Muggah, R. (2007) Armed Violence in Africa: Reflections on the Costs of Crime and Conflict. New York: United Nations Development Programme.

Muller, E. N. and Seligson, M. A. (1987) Inequality and Insurgency, American Political Science Review8l(2):425-45l.

Murshed, S.M. (2007) The conflict-growth nexus and the poverty of nations, DESA Working Paper No. 43. United Nations Department of Economic and Social Affairs. 
Mustapha, A. R. (2000) Transformation of Minority Identities in Post-Colonial Nigeria" In Jega, A. (ed.) Identity Transformation and Identity Politics under Structural Adjustment in Nigeria, Uppsala: Ndrdiska Afrikainstitutet.

Nnoli, O. (1978) Ethnic Politics in Nigeria, Enugu: Fourth Dimension Press.

Nzongola-Ntalaja, G. (1987) Revolution and Counter-Revolution in Africa, London: Institute for Africa Alternatives / Zed Press.

Nzongola-Ntalaja, G. (1998) The State and Democracy in Africa, In Nzongola-Ntalaja, G. (ed.) The State and Democracy in Africa, Trenton, New Jersey: Africa World Press.

Oberschall,.A. (1978) Theories of Social Conflict, Annual Review of Sociology, 4: 291-315.

,OECD (2007) OECD-DAC Foreword to Handbook of Security sector Reform (SSR): Supporting Security and Justice. Paris: Organisation for Economic Co-operation and Development.

Olaniyi, R. (2006) From Citizens to Strangers: British Rule and the Transformation of Yoruba Migrants Identity in Kano - 1913-1958,. In Akinwumi, O. et al (eds), Inter-Group Relations in Nigeria during the $19^{\text {th }}$ and $20^{\prime \prime}$ ' Centuries. Makurdi: Aboki Publishers.

Otite, O. (1990) Ethnic Pluralism and Ethnicity in Nigeria. Ibadan: Shaneson C. I. Limited.

Perz, O.J. (2003/2004) Democratic Legitimacy and Public Insecurity: Crime and Democracy in El Salvador and Guatemala, Political Science Quarterly, Vol. 118, No. 4 (Winter, 2003/2004), pp. 627-644.

Schmid, AP. (1998) Common Causes of Violent Crime and Conflicts, Melup, I. ed. Violent Crime and Conflict. Milano, Italy: The International Scientific and Professional Advisory Council for the United Nations Crime Prevention and Criminal Justice Programme.

Sellin, T. (1938). Culture Conflict and Crime, New York: Social Science Research Council

Simone, A. (2001) On the Worlding of African Cities, African Studies Review, Vol. 44, No. 2: 15-41.

Stewart, F., (2003) Conflict and the Millennium Development Goals, Journal of Human Development, Vol.4, No. $3,325-351$.

Stewart, F. (2004) Development and Security. CRISE Working Paper 3. Oxford: CRISE

Stewart, Frances (2000) Crisis Prevention: Tackling Horizontal Inequalities. Oxford Development Studies, 28 (3): 245-62.

Suberu, R. (2001) Federalism and Ethnic Conflict in Nigeria. Washington, D.C.: United States Institute of Peace.

Tilly, C. (2003) The Politics of Collective Violence. Cambridge: Cambridge University Press. 
UNCHS (HABITAT) (1996) An Urbanizing World: Global Report on Human Settlements 1996, Oxford: Oxford University Press.

Vanderschueren, F. (1996) From violence to justice and security in cities, Environment and Urbanization Vol. 8, No 1, April, 93-112.

Weber, M. (1961) The City, translated and edited by Don Martindale and Gertrend Newirth, Heinemann, London.

Winton, A. (2004). Urban violence: a guide to the literature, . Environment and Urbanization, 16: 165-184.

Wirth, L. (1938) Urbanism as a Way of Life, American Journal of Sociology, 743-755

Wirth, L. (1940) Ideological Aspects of Social Disorganization, American Sociological Review, Vol. 5, No. 4: $472-482$.

Wolfgang, M.E. and Ferracutti, F (1967) The Subculture of Violence. London: Tavistock.

World Bank. (2011) Conflict, Security and Development, New York: World Development Report World Bank 